Egyptian Journal of Geology

\title{
Morphotectonic Evolution of Qaret El Sheikh Abdallah Depres- sions and Denuded Paleo-Karst in the White Desert, El Bahariya- Farafra Karst Territory, Egypt.
}

\author{
M. El Aref*, A. Salama** and M. Hammed ${ }^{*}$ \\ *Department of Geology, Faculty of Science, Cairo University, Giza, Egypt. \\ ** Nature Conservation Sector, Egyptian Environmental Affairs Agency, Maadi, Cairo, \\ Egypt.
}

\begin{abstract}
$\mathbf{T}$ HE Late Cretaceous-Early Eocene carbonate sequences of the White Desert of Egypt exhibit amazing complex paleo-humid karst landforms, so it was declared as a nature-protected area since 2002. Two karst depressions of El Sheikh Abdallah and the Crystal Mountain (Qaret El Sheikh Abdallah) are identified by detailed fieldwork and GIS morphometric analysis of the digital elevation model of the northern part of the White Desert. These depressions are verified as two separate karst uvalas between the major karst poljes of El Bahariya and Farafra karst territory with northeast alignment. The sea-level drops and uplifting phases of the carbonate sequences of the uvalas, associated with the major compressional events of the Syrian arc (Cretaceous-Paleogene) and Oligo-Miocene extensional tectonics in north Egypt caused the development of three major stratigraphic breaks (fossilized paleo-karst surfaces) of Late Cretaceous-Palaeocene, Palaeocene-Early Eocene, and post-Early Eocene (Oligocene-Miocene). Along these fossilized surfaces, paleokarst features and sediments are detected and described. El Sheikh Abdallah and the Crystal Mountain depressions (uvalas) are also dominated by exposed (surface) complex karst features such as unroofed caves, widened joints, sinkholes, collapse breccia's, and solution channels, together with sporadic remains of uncovered autochthonous and allochthones paleo-cave sediments. The recognized stratigraphic breaks and their paleokarst features and the subsequent surface denudation helped to propose a morphotectonic evolutionary model for the exposed karst landscape and the denuded karst features of El Sheikh Abdallah-Crystal Mountain uvalas.
\end{abstract}

Keywords: Fossilized paleo-karst, Crystal Mountain, uvalas, stratigraphic breaks, surface karst, unroofed cave facies, protected area, Poljes, Egypt.

\section{Introduction}

El Bahariya-Farafra karst territory (Fig.1) is an attractive tourist example of the Desert Oasis, in one of the highest hyper-arid deserts in the world with the scarcest rainfall rate at present and during the last 7000 years. The territory comprises two important protected areas which are declared under law number $102 / 1983$ in the framework of protected areas in Egypt (Fig.1). The first one is named White Desert National Park declared by Ministerial Decree No. 2219/2002 to protect the spectacular scenery, erosional chalky karst landscape, the associated karst landforms, and erosional features (El Aref, et al. 2017a). The second one is known as Al Wahat El Bahariya Protected Area which is declared by the Ministerial Decree No. 2656/2010 to protect the site of the natural heritage of the Cenomanian Dinosaur site and the ferricrete capping (duricrusted) black cone

Corresponding author: Hammed, Mohamed Saleh Hassan, Email: salehhammed@cu.edu.eg

Received 27/10/2021; Accepted 07/11/2021

DOI: 10.21608/egjg.2021.103324.1011

C2021 National Information and Documentation Center (NIDOC) 
hills. The White Desert National Park scored the highest in total value and final ranking among the inventory and assessment of El BahariyaFarafra geomophosites (El Aref, et al., 2017b).

Closed depressions are the most important morphologic features of the Western Desert of Egypt. Most of them are characterized by the distribution of natural springs, which have attracted people since Pharaonic time to inhabit it. Most of the Oasis's names were inherited from their depressions. Before the pioneering work of El Aref, et al. (1987), who attributed the origin of the carbonate depressions and related karst sediments to multi paleo-karstification processes, the formation of the Western Desert Depressions of Egypt was attributed to wind or tectonic actions (Ball, 1939, Knetsch and Yallouze, 1955; Said, 1960 \&1962).

One of the main difficulties of geomorphic interpretation of landforms is that the weathering and erosion processes, which very often play an integral role in the geomorphic evolution of a region, tend to obscure, and obliterate evidence of pervasive events on the surface (Piccini, 1998). Nevertheless, the record of past events is preserved in a karst area much longer and in more detail than in other continental environments, primarily because these events are expressed in the pattern of subsurface features such as caves (Palmer,1984). However, the term paleokarst in ancient carbonate sequences is now common, most of the published papers concentrate on one step only, whereas the multiple conformities of complex karstification establish combined patterns of porosity in an individual region (Nádor, 1993). Zhang, et al. (2010) defined paleo-karstic surface as a surface, preserved within a carbonate succession that was formed by the effects of regional tectonic uplift and karst erosion. The presence of a paleo-karstic surface indicates that during the deposition of the full rock sequence, the young rocks were exposed to the effects of surface (subaerial) erosion. During such a non-depositional and erosional phase, a full suite of karst features, including caves could be developed (NCEA-W, 2002). Fossil karst (buried karst) is karst topography entirely buried by relatively younger post-rock or sediments and not part of the contemporary landscape (NCEA-W, 2002). Field (1999) defined denuded karst as subsoil karst that has been exposed by erosion and removal of its cover, it is characterized by several different cave patterns, due to the exposure in earlier stages, where old cave patterns influence the development of the karst landscape and hydrology (Klimchouk and Ford, 2000). El Sheikh Abdallah and Crystal Mountain regions have a complex history of karst concerning tectonic uplift in the El Bahariya-Farafra karst territory. Numerous studies were done on the El Bahariya-Farafra karst territory (e.g. Abu Khadra, et al., 1987; El Aref, et al., 1987; Sokkar, 1991; El Aref, 1994; Pickford, et al., 2006; Wanas, et al., 2008.; Pickford, et al., 2010; El Aref, et al., 2017a; El Aref, 2020). There are some attempts to identify the age of the karst sediments of these areas through fossils found in the El Sheikh Abdallah red soil matrix breccias, comprising anurans, snakes, soricids, bats, galagids, hystricids, and glirids which indicate that the region enjoyed a humid paleoclimatic regime between 11 and $10 \mathrm{Ma}$, with mean annual rainfall more than $750 \mathrm{~mm}$, and possibly as much as $1200 \mathrm{~mm}$ (Picford, et al., 2010). The red soils of the exposed denuded karst of the El Bahariya-Farafra plateau contain small vertebrate fossils dated back to the late Miocene (Pickford, et al., 2006 \& Wanas, et al., 2008., Mein and Pickford, 2010). In the Eastern Desert, in east Beni Suef (Khashm El-Raqaba) limestone quarry, small Miocene fossil vertebrates of snakes, rodents and bats, have been recovered from exposed karst red soil filling fracture cutting across into Eocene limestone (Gunnell, et al., 2016).

Brook, et al. (2000) used the U-series to determine the age of speleothems of the Djara Cave, locating southeastern of the study area, and encountered within Eocene limestones. None of the secondary carbonates have a Holocene age, despite archaeological evidence of ancient peoples both in the cave and on the ground of a more humid period of climate from about 11.5 to $6.5 \mathrm{ka}$ (Brook, et al. 2000). Dabous and Osmond J. (2000) studied some samples collected from stalagmites of the intra-Eocene Wadi Sannur cave, Eastern Desert, by using the uranium-thorium (U-Th) dating method to detect the age of the speleothems. The $\mathrm{U}$ and $\mathrm{Th}$ isotopic data suggest that there have been at least two periods of $U$ mobilization and deposition. One would be the time of initial formation of the speleothems, probably somewhat less than 200,000 years ago and the other would be the time of subsequent leaching. 


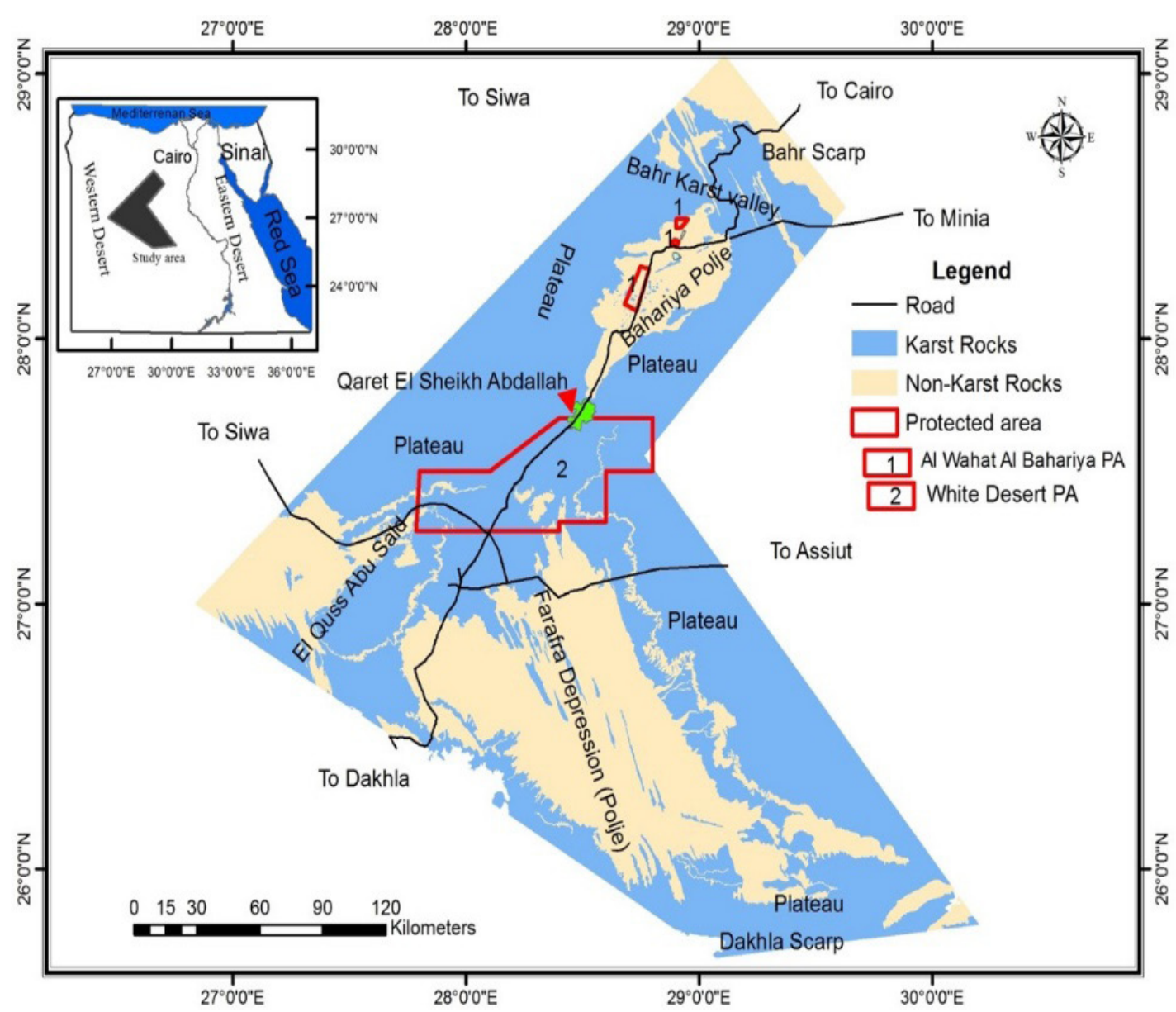

Fig. 1. Location map of the study area and encompasses protectorates. Note the distribution of karst/ non karst rocks.

In the present work, we present a synthesis of the main complex paleo-karst history and establish a comprehensive genetic model for the formation of the present-day astonishing of El Sheikh Abdallah and Crystal Mountain karst depressions (uvales) of Qaret El Sheikh Abdallah, El Bahariya-Farafra Karst Territory.

\section{Methodology}

Our methodology is depending on the detailed field observations and documentation on the entire surface of the study area. A detailed investigation was carried out on the surface sections between all representative rock units to identify their stratigraphic settings, their lower and upper boundaries, and hiatus (sequence boundaries). Data collected in the field by using GPS (Geographic Position System ) were integrated with satellite images and a digital elevation model (DEM) created with SRTM (Shuttle Radar Topography Mission) data (90 $\mathrm{m}$ spatial resolution) with using
GIS (ArcGIS 10.2) to identify the different types of depressions. The recognized gaps in deposition are also emphasized by a chronostratigraphic correlation between the measured surface sections and the available subsurface data and the related biozones in the entire area. Analyses on the paleogeomorphology and paleo-fault were based on the regional geological setting combined with lithological and paleontological data.

\section{Geologic setting of El Bahariya-Farafra karst territory}

Most of the territory is covered by CretaceousEocene karstified carbonate sequences punctuated by paleo-karst (fossilized karst) surfaces of variable magnitudes, in addition to minor exposures of Oligo-Miocene clastic rocks and basalt eruptions (Fig. 2). The exposed carbonate sequences exhibit a characterized karst landforms that were prevailed before the recent arid climatic condition. 


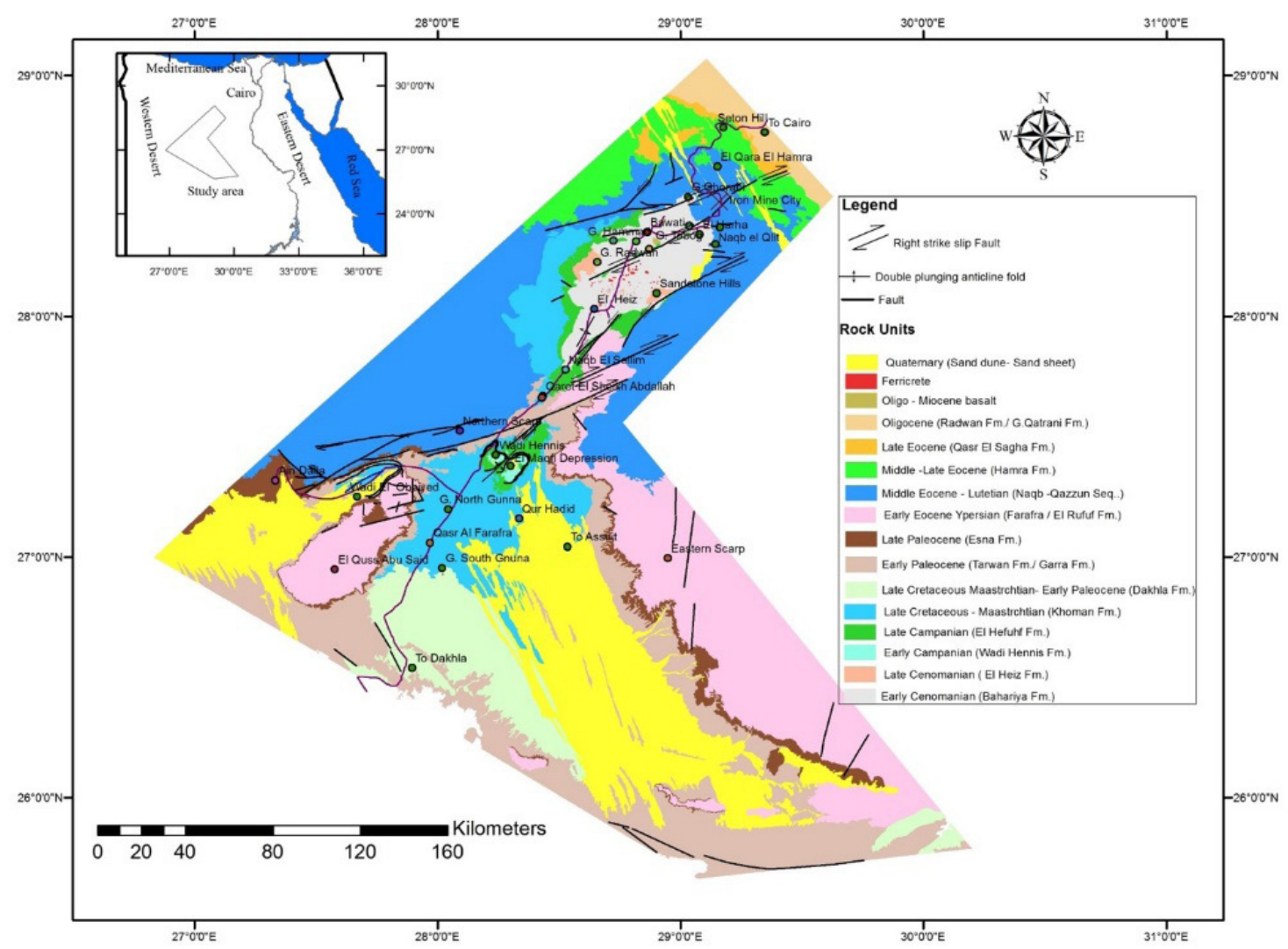

Fig. 2. Geological map of El Bahariya-Farafra Region (modified after El Akkad and Issawi, 1963, Moustafa, et al., 2003, and Mazzini, et al., 2019).

Among the most particular post-Middle Eocene (Oligocene.- Miocene to Quaternary ?) exposed karst surface features appearing on the surface (Fig. $3 \& 4$ ) are open karst depressions (from large scale poljes and uvalas down to dolines and sinkholes), swallow basins and holes, polygonal tower and cone or kegel karst forms, blind rivers and valleys, sinking streams, subterranean drainage, grikes and karren features, pavements and highly corroded bedrocks, residuum and rock remnants, soil products and calcite reprecipitates. The karst processes responsible for the development of the apparent surface karst led to the denudation and destruction of some of the exposed fossilized paleokarst surfaces and the associated precipitates forming denuded paleokarst features. In the low land areas and on the floor of the karst depressions, karst features are covered by Quaternary to Recent sediments (e.g. sand dunes, playa deposits, salt lakes, and vegetation) forming exhumed karst (Klimchouk and Ford, 2000). On the other hand, the summits of most of the remaining karstified carbonates forms are encrusted by variable types of surficial duricrusts (e.g. calcrete, silcrete, dolocrete, and ferricrite).

Structurally, El Bahariya-Farafra karst territory is dissected with a set of ENE-oriented structural belts recognized on the newly constructed geologic map (Fig. 2). According to the surface geology and subsurface data of the nearby areas (Moustafa, et al., 2003 and Farooqui, et al., 2012), these structural belts have multi-deformational phases represented by the Turonian? Late Senonian/ -Eocene transpressional inversion of inherited extensional Jurassic/Early Cretaceous faults (Fig. 2). The southern Baharyia structural belt shows severe Late Cretaceous and Eocene inversion in comparison to the northern Baharyia and Farafra belts. This differential inversion had impacts on the depositional and erosion in the whole territory. Later, the territory was subjected to the Oligo-Miocene extension and associated volcanicity. The tectonic evolution of the territory shows great similarity to the deformation of the

Egypt. J. Geo. Vol. 65 (2021) 
'tectonically unstable' area of the northern Western Desert (Moustafa, et al., 2003). The uplifting and subsidence associated with these tectonics were expressed by the various stratigraphic hiatus and boundaries (Fig. 5). Moreover, this structural framework in form of faulting and folding produced the fabric heterogeneities and fracturization of the various rock sequences and developments of the secondary porosity, permeability, weak lines, and structurally controlled solution passages in the carbonate country rocks. These played a critical role in the shaping of the surface karst landforms and resultant zonation in the studied territory during post-uplifting karstification processes (El Aref, et al., 2017a). El Sheihk Abdalla and Crystal Mountain Depressions (Qaret El Sheihk Abdallah) can be considered as the most significant and fantastic exposed (open) karst areas within the Central Western Desert as they reveal remarkable exposed karst features and products as well as degradation and rejuvenation processes during subsequent karst events.

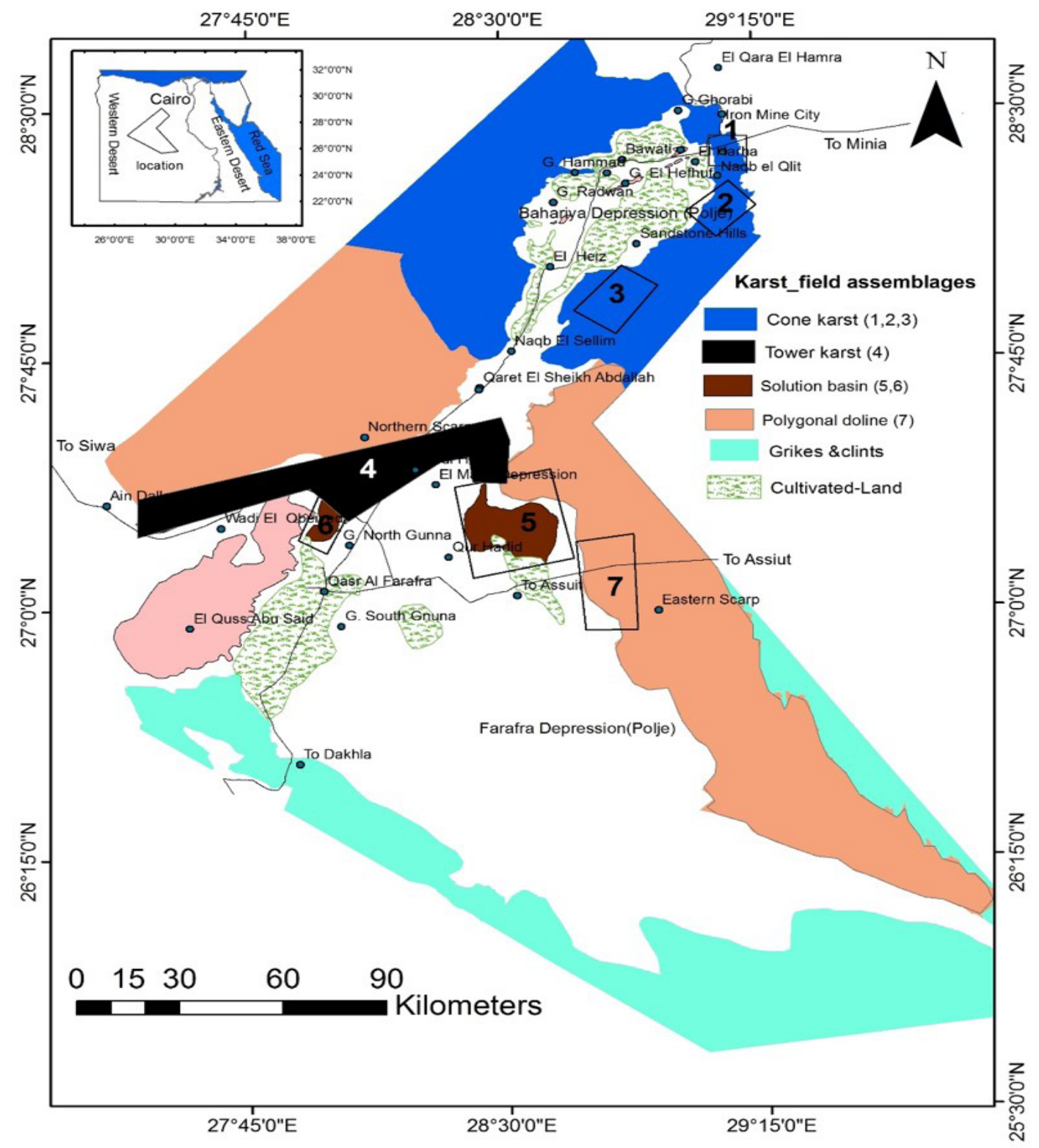

Fig. 3. Karst landforms zonation of El Bahariya- Farafra karst Territory (El Aref, et al., 2017a). 
During the Cenomanian, the Bahariya-Farafra platform was located on a passive continental margin whereas, by the Turonian-Santonian, the northern part was forming a structural high within the basin with continuous sedimentation in the southern part including Qaret El Sheikh Abdallah. There was differential sedimentation and erosion between the northern and southern parts of the concerning territory during the Maastrichtian, Palaeocene, and Lower Eocene. During the Palaeocene, the Bahariya structure formed a positive inverted area while Qaret El Sheihk Abdallah and Farafra received the deposition of the Palaeocene chalks. The absence of the Early Eocene-Palaeocene Esna Shale at the northern part of the Farafra Oasis and Qaret El Sheikh Abdallah indicates that uplifting of the two areas took place during the deposition of the lower part of the Esna shale. During Early Eocene, the whole area submerged receiving the deposition of the Early Eocene Farafra dolostone sequence. With the beginning of Lutetian time, sea drowns the Bahariya- Farafra paleo-highs formed positive blocks which were subjected to denudation and deep weathering since Late Cretaceous time (El Aref, 1994). The northward retreat of the Middle Eocene Tethyan paleo-shoreline, accompanied by the second culmination of the transpressional inversion took place and led to the uplifting of the Cretaceous strata in El Bahariya-Farafra region, whereas a succession of fossiliferous carbonate facies (i.e., the Lutetioan Naqb and Qazun successions) onlapped different Cretaceous rock units in the north of El Bahariya paleo-highs, meanwhile lateritization inducing paleo-karstification acted upon the uplifted Cretaceous-Early Eocene blocks of the hinterlands (El Aref, 1994 $\&$ 2020). During the post-Middle Eocene to Quaternary time, a further northward retreat of the shoreline took place leaving behind uplifted positive lands under erosions, synchronized with river incisions and fluvial deposition. It is worth mentioning that humid paleoclimate prevailed during most of the Oligocene and Miocene periods.

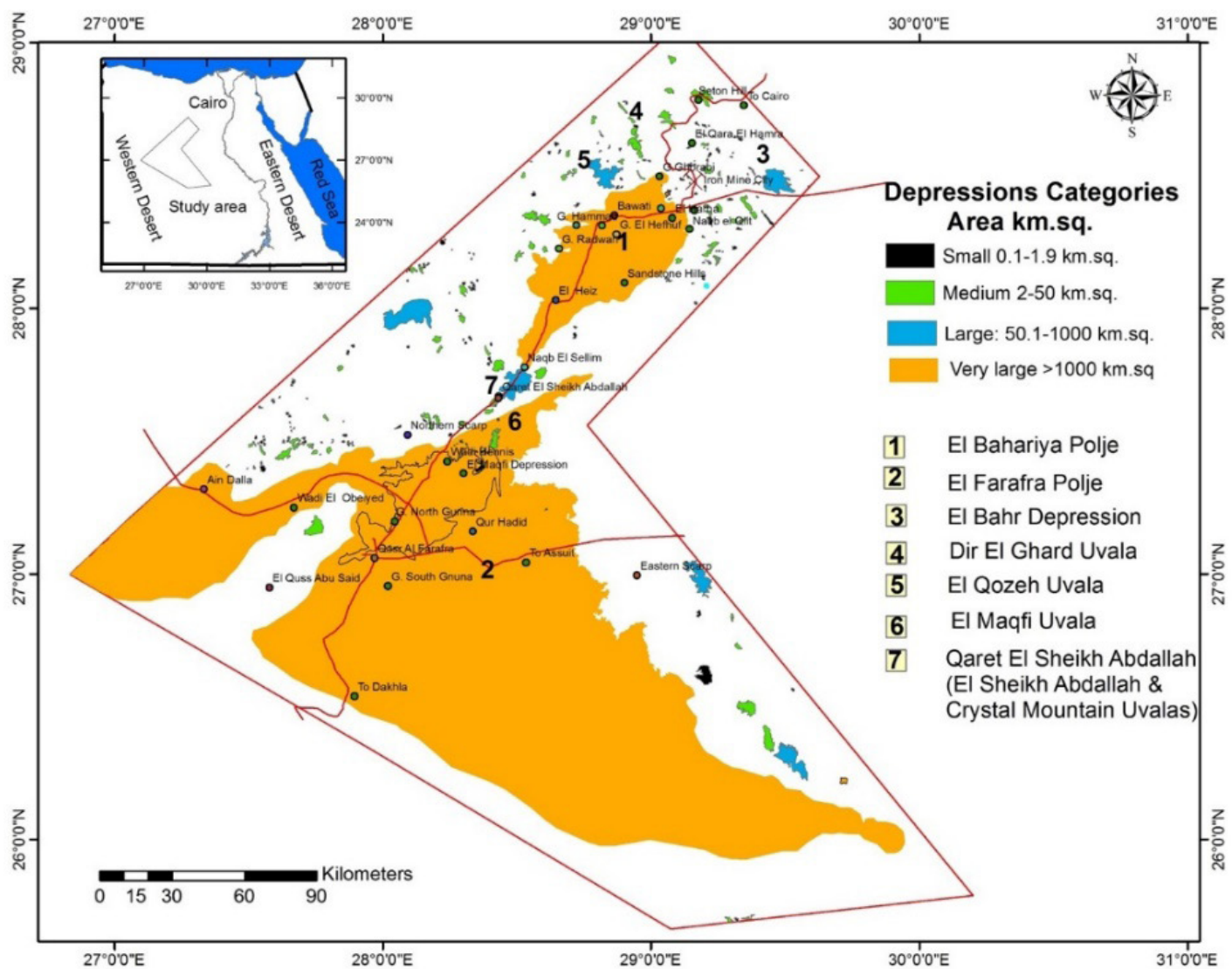

Fig. 4. Distribution and classification of the karst depressions of EI Bahariya- Farafra karst Territory (EI Aref, et al., 2017a).

Egypt. J. Geo. Vol. 65 (2021) 


\section{Stratigraphic discontinuities}

Karst evolution depends especially on the time available for processes and the geographical and geological conditions of the exposure of the rocks. Unconformities affect the karst stratigraphy across the time-span available for subaerial processes. Details of the different stratigraphic discontinuities of El Bahariya- Farafra karst territory is described according to El Aref, et al., (2017a) as follows:

I. Inter-formational fossilized major sequence boundaries displaying break in sedimentation during periods of relatively long-lived exposure and sea-level fall. These interformational boundaries include the five following unconformities and paleokarst boundaries which were denoted by the symbol MK in Fig. (5):

1. Cretaceous - Paleocene (K/P) paleo-karst boundary,

2. Cenomanian-Middle Eocene unconformity,

3. Intra-Middle Eocene paleo-karst boundary,
4. Early Eocene - Miocene paleo-karst boundary,

5. Middle to late Eocene - Oligocene paleokarst boundary.

II. Inter-formational and Intra-formational fossilized minor paleo-karst delineating some rock unit bounders during relatively short periods of exposures which were denoted in Figure 5 by the symbol $\mathrm{mK}$.

III. Intra-formational fossilized (depositional) micropaleo-karst surfaces that define the topmost carbonate layers associated with meter-scale swallowing upward cycles and indicate breaks of sedimentation during periods of very short-lived exposures (denoted by the symbol mk in Fig. 5), and

IV. Exposed karst (surface karst) landforms (MioceneQaternay?), responsible for the sculpturing and development of the exposed karst landscape, distinguish this karst territory (denoted by the symbol SK in Fig. 5).

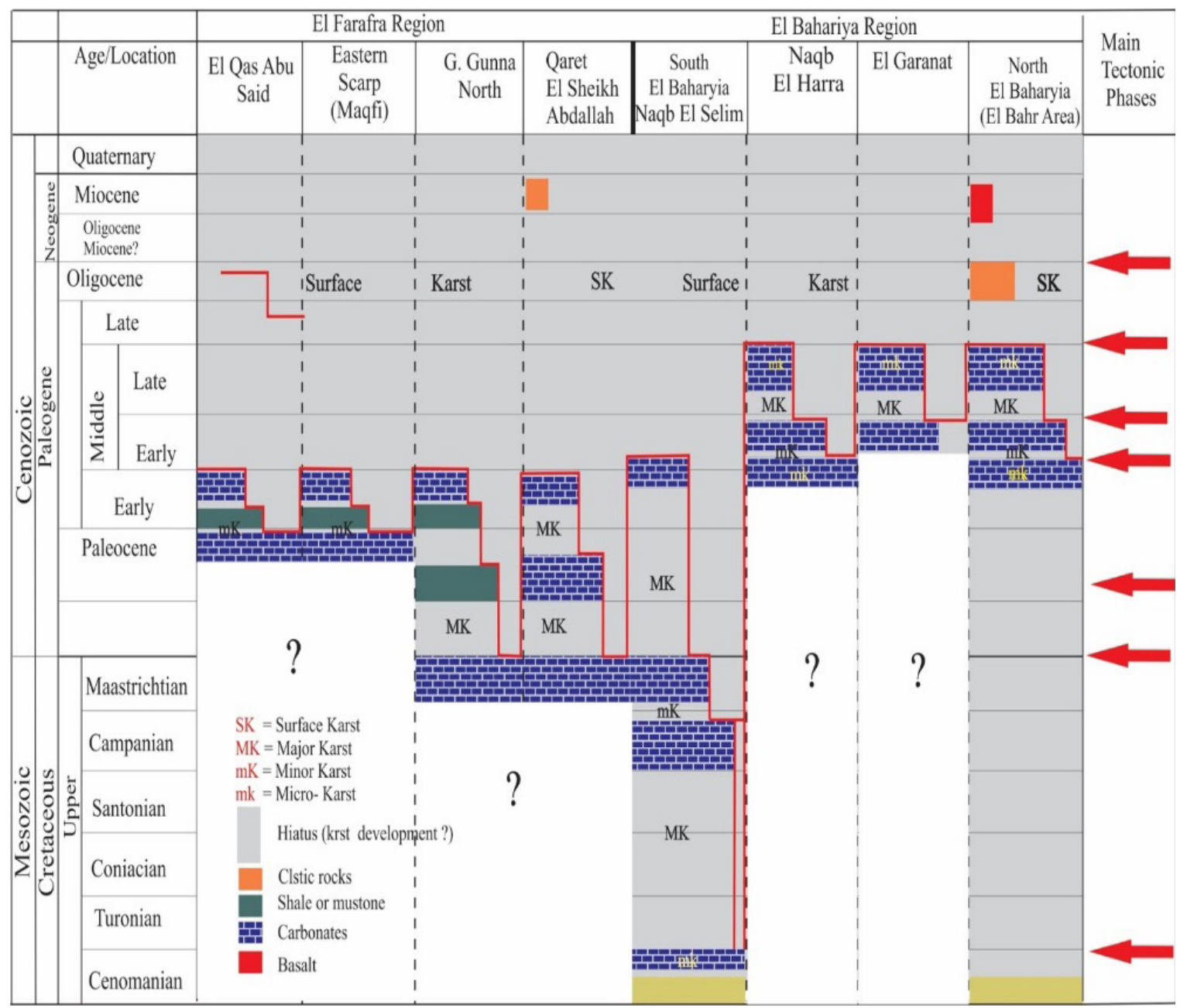

Fig. 5. Stratigraphic gaps (paleo-karst surface types) of El Bahariya-Farafra territory (EI Aref, et al., 2017a). 
The present-day Bahariya-Farafra landforms appear to be generated during general lowering of the landscape over long periods of humid climates, most probably during the rainy periods of the post-Middle Eocene-Quaternary time before the prevailing of the recent arid to hyper-arid conditions (Fig. 6). These paleo-erosion (paleokarst) surfaces are identified by the detection and delineation of high-laying indurated Fe laterites, karst profiles, and surficial duricrusts covering the beveled summits of flat-lying residual hills. Each of which is of consistent altitude range and demarcate certain paleo-erosion level resulting from an old erosion cycle (S1-S4, Fig. 6). The relatively old surfaces are topographically inverted through subsequent etch planation and pedimentation processes involving destruction and stripping of the high-lying duricrusts, lateritic deposits and karst regoliths and the exposure of the bedrock forms; incision of valleys; slope and scarp retreat; gradual consuming of the residual hills; pedimentation and pavementation and development of younger exposed karst surface (S1-S4, Fig. 6).

\section{Evolution of El Sheikh Abdallah and crystal mountain karst landform}

Qaret El Sheikh Abdallah area is located at the northern part of the White Desert Protected Area (Fig.1-4) and encompasses two NE oriented karst depressions (El Sheikh Abdallah and Crystal Mountain uvalas), excavated in El Bahariya-Farafra plateau (Fig. 3, 4 \&7). The maximum elevation of the plateau encircles these depressions is recorded in the eastern part of the depressions, up to $256 \mathrm{~m}$ a.s.l., which is highly pitted by solution dolines, cockpits, and cone hills, while, the western plateau is commonly covered by post-Eocene fluvial sandstones and conglomerates, rising 215-240 m a.s.l. The floor of the depressions is generally flat and slightly undulated (190-200 $\mathrm{m}$ a.s.l), especially in the north-eastern part of El Sheik Abdallah depression, and with rugged mountainous relief at the south-western part. Towards the Crystal Mountain Depression, the floor is dominated by parallel series of connected and disconnected carbonate conical hills, surrounded by a group of incised valleys with a wide distribution of unroofed caves and cave facies, stream sinks, and matrixsupported red soils (Fig. 7, 8A \& B). Progressive landform denudation through gradual widening and deepening of the valleys, slope retreat, and consumption of the carbonate cone hills led to the formation of highly collapsed and denuded isolated carbonate hillocks and or discrete piles of rubbles (Fig. $8 \mathrm{C} \& \mathrm{D}$ ). Interrupted fluvial ridges, unroofed cave fillings, accumulation of varieties of red soils, ruin forms, domes, and pillars of different compositions and internal and external textures rise abruptly from the surrounding lowlands or along the present-day ground surface. The sequences cropping out in Qaret El Sheikh Abdallah and the associated Depressions are Late CretaceousEarly Paleocene chalks (Khoman and Tarawan formations) and Early Eocene dolostones (Farafra Formation) truncated by Post Eocene-Miocene/ Oligocene!?) fluvial sediments and Quaternary sediments (Fig. 9).

In the bare hill slopes, three inter-formational major paleokarst boundaries (paleo-surfaces) are recognized (Fig.9), that confirmed by the equivalent age assignment and gaps of sedimentation shown in the correlation chart of figure (10). The time gap evaluated 9.5 million years from late Maastrichtian due to the absence of biozones CF1 and Cf2 and till $\mathrm{p} 4 \mathrm{~b}$ where the Tarawan formation deposited and the second gap started from Late Thanetian by the absence of $\mathrm{p} 5$ to E5 and this gap evaluated by 6.5 million years, the third gap calculated by 22 million years from E8 to E16 and evidenced by the absence of Middle and Late Eocene and Early Oligocene (Fig.10). The recognized paleokarst surfaces include:

- Early Eocene - Oligo-Miocene, demarcating the top part of the Early Eocene sequence just beneath the Miocene (Oligocene?) fluvial clastics and along which the original dolostone layers become highly fractured, silicified, and brecciated, especially along fossilized small scale solution channels and widened karren of variable types (Figs. 11 A\& B). Gradual striping of the fluvial sediments and the underlying karstified dolostones giving rise to detached dolostone blokes and breccia's, encrusted by silcrete crust (Fig. 11 B).

- Paleocene-Early Eocene sequence boundary of a highly undulated top surface of rubbly chalk often caped by red soils, separating the Paleocene chalk from the overlying Early Eocene dolostones (Fig. 9, 11 C \& D), whereas the Paleocene chalks are dominated by an anastomosing pattern of solution opening caves and cavities of variable sizes and shapes developed along inclined and vertical fractures or along bedding planes (Figs. 11 C \& D). These are completely or partially filled with remarkable red sandy soils intercalated with different generations of calcite precipitates and speleothems (Fig. 11 E). In some places, the 
rock sequences and the hosted karst features and sediments are highly tilted, folded, and faulted.

- Post - Maastrichtian - Lower Paleocene sequence boundary demarcated by highly undulated upper surface with abundant solution and collapse small-scale dolines and V-shaped sinkholes or bowl-shaped solution basins filled with basal rubbly conglomerates. Infilled solution channels and enlarged fractures often cut across the exposed Cretaceous and Paleocene sequences. The progressive stage of fracturing, striping, and fragmentation of these rocks gave rise to clast-supported chaotic breccia or conglomerates (Figs. 11 E-H). The Cretaceous chalks are intensively faulted and commonly intersected by a set of initial fractures formed and extended from the surface downwards and acted as a weak line for dissolution and continuous enlargements of vertical and inclined passages and irregular cavities, internally lined by crustified calcite and partially filled with red soils and calcite speleothems. The resulted passages are often connected with elongated large-scale cavity systems of different levels, sandwiched between the chalk layers (Fig.11 E - H).
G. Gunna El Bahariy

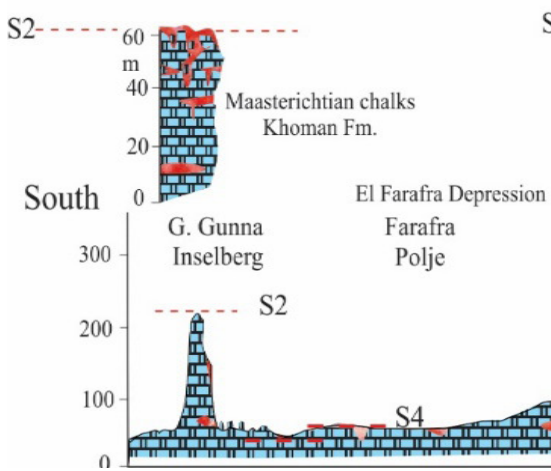

Naqb El Selem Qaret El Sheikh Abdallah
Naqb El Farafra

Opk Oligo-Miocenefluvials
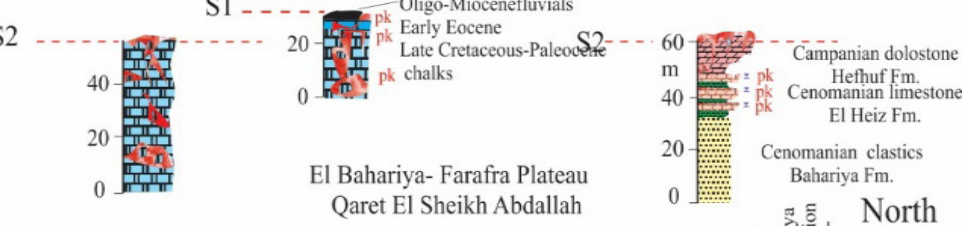
Qaret El Sheikh Abdallah

0 ]...... North

Fig. 6. Schematic profile of the exposed paleo-erosion (paleo-karst) surfaces (S1-S4) of EI Bahariya-Farafra karst territory and the main north-dipping inverted structural belts(faults) bounded Shaikh Abdallah, (stratigraphic sections are compiled from EI Aref (1987, 1994, 2020), Sokkar (1991), Abu Khadra, et al.(1987) and El Aref, et al. (1987 \&2017a), with minor modification.

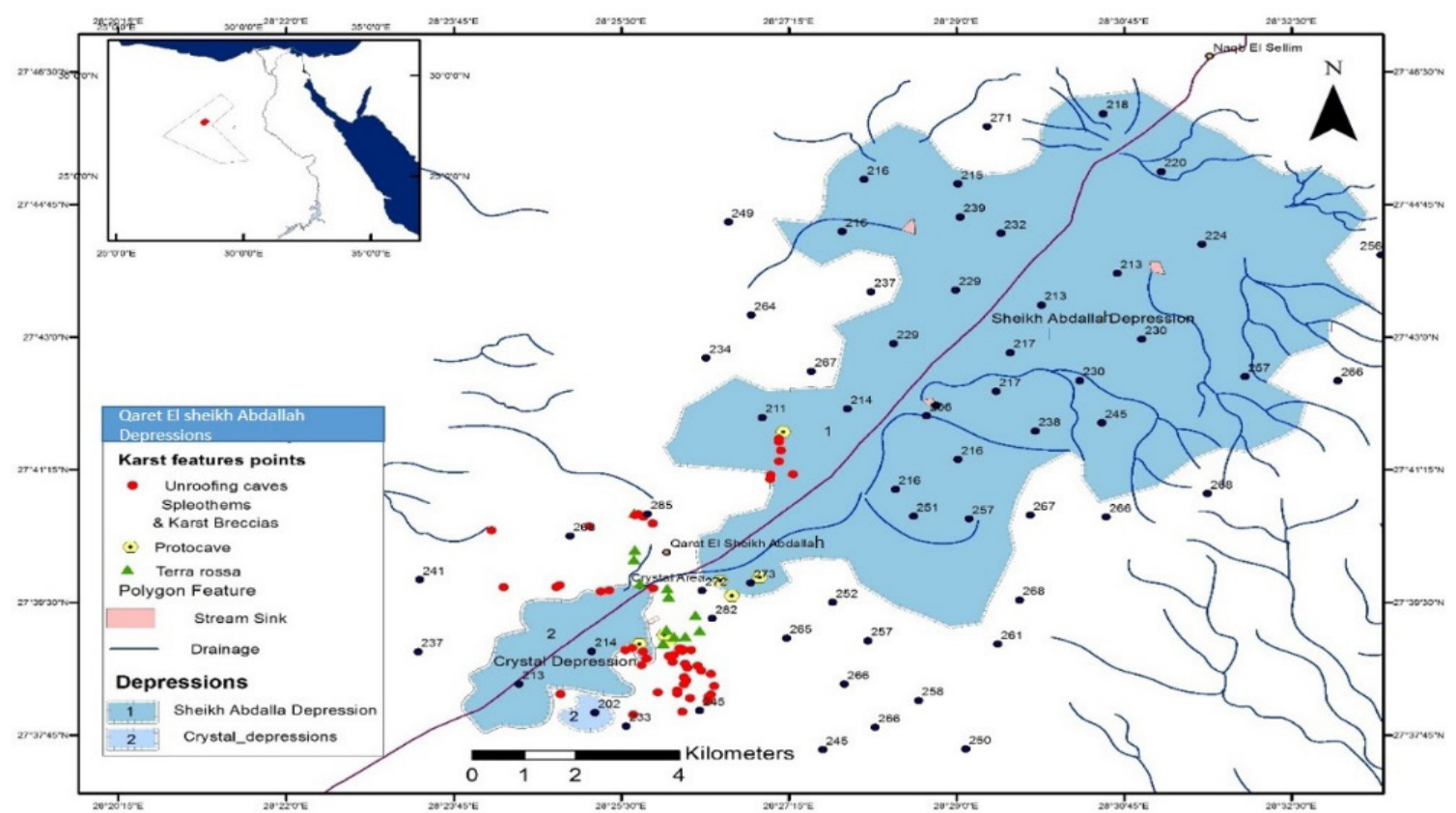

Fig. 7. Karst features associated with EI Sheikh Abdallah and crystal Mountain Depressions (Qaret EI Sheihk Abdallah). 

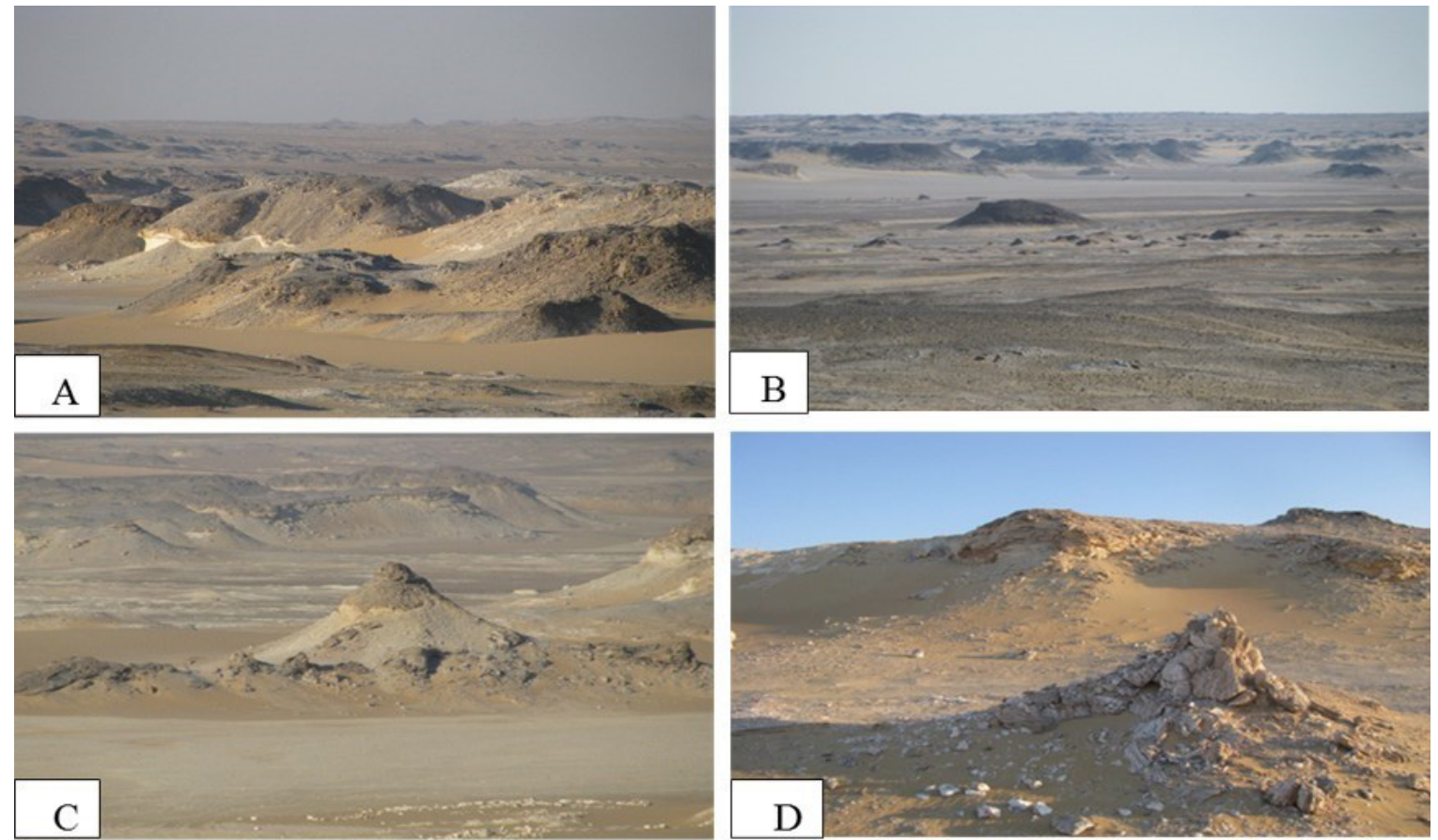

Fig. 8. Field photographs showing; A) connected to nonconnected rugged carbonate hills. B) wide valley with residual carbonate cone hills. C) very much consumed conical hill. D) a heap of carbonate rubbles.

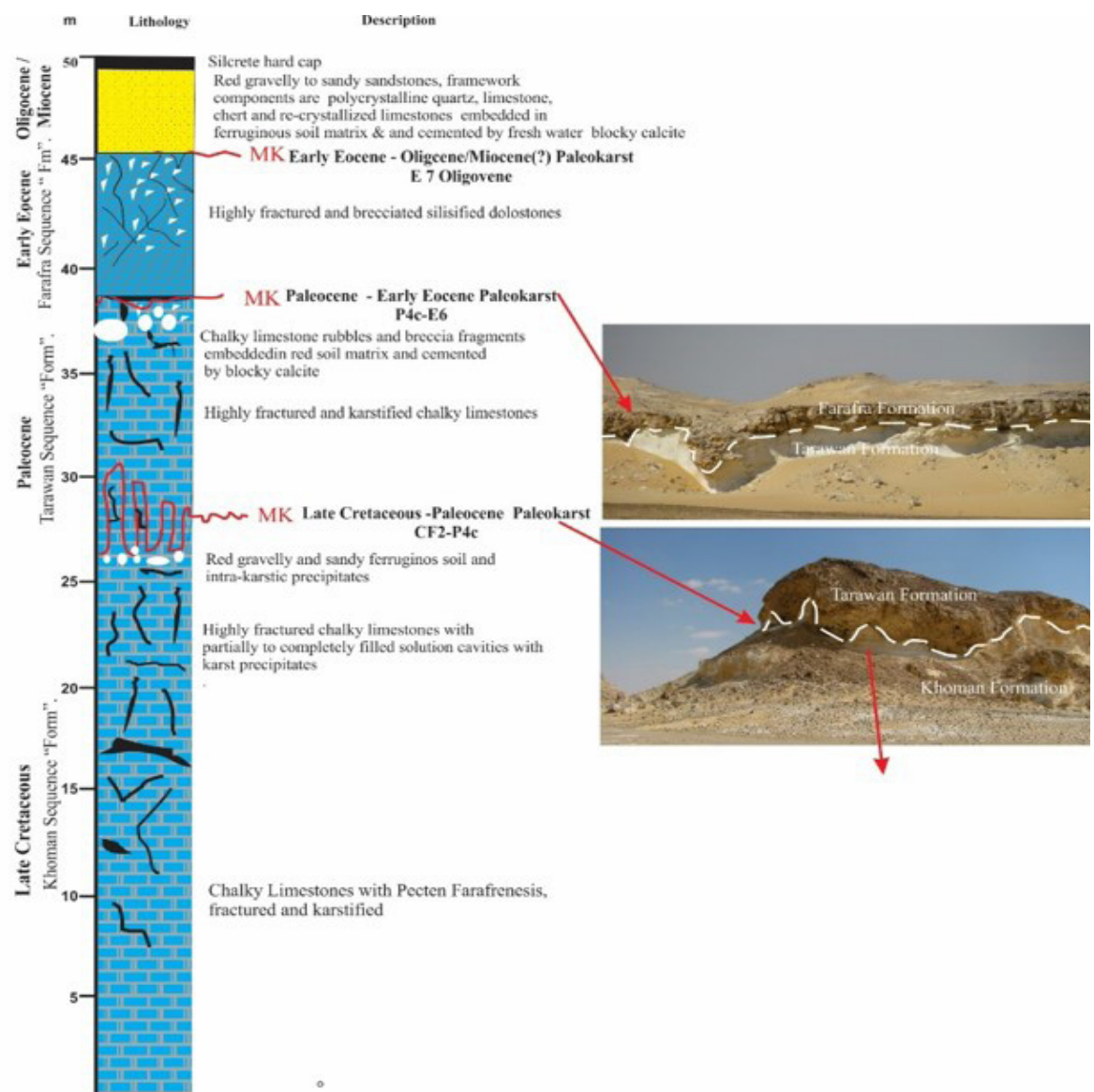

Fig. 9. Measured stratigraphic section of the rock sequences of Qaret EI Sheihk Abdallah.

Egypt. J. Geo. Vol. 65 (2021) 


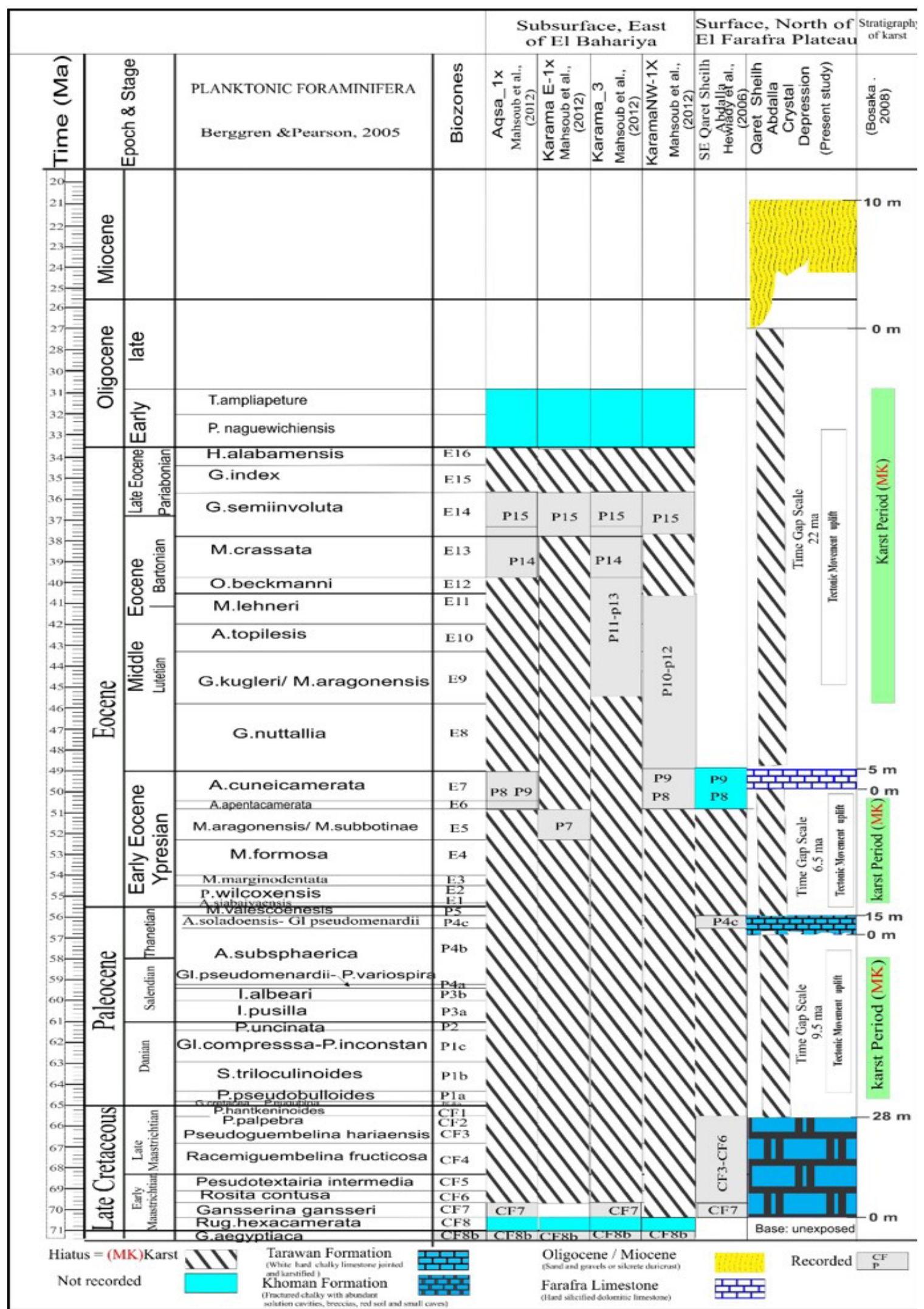

Fig. 10. Correlation chart showing the age assignment of the depositional sequences and paleokarst surfaces compiled from surface and subsurface stratigraphic sections and based on the planktonic foraminiferal biozones. 

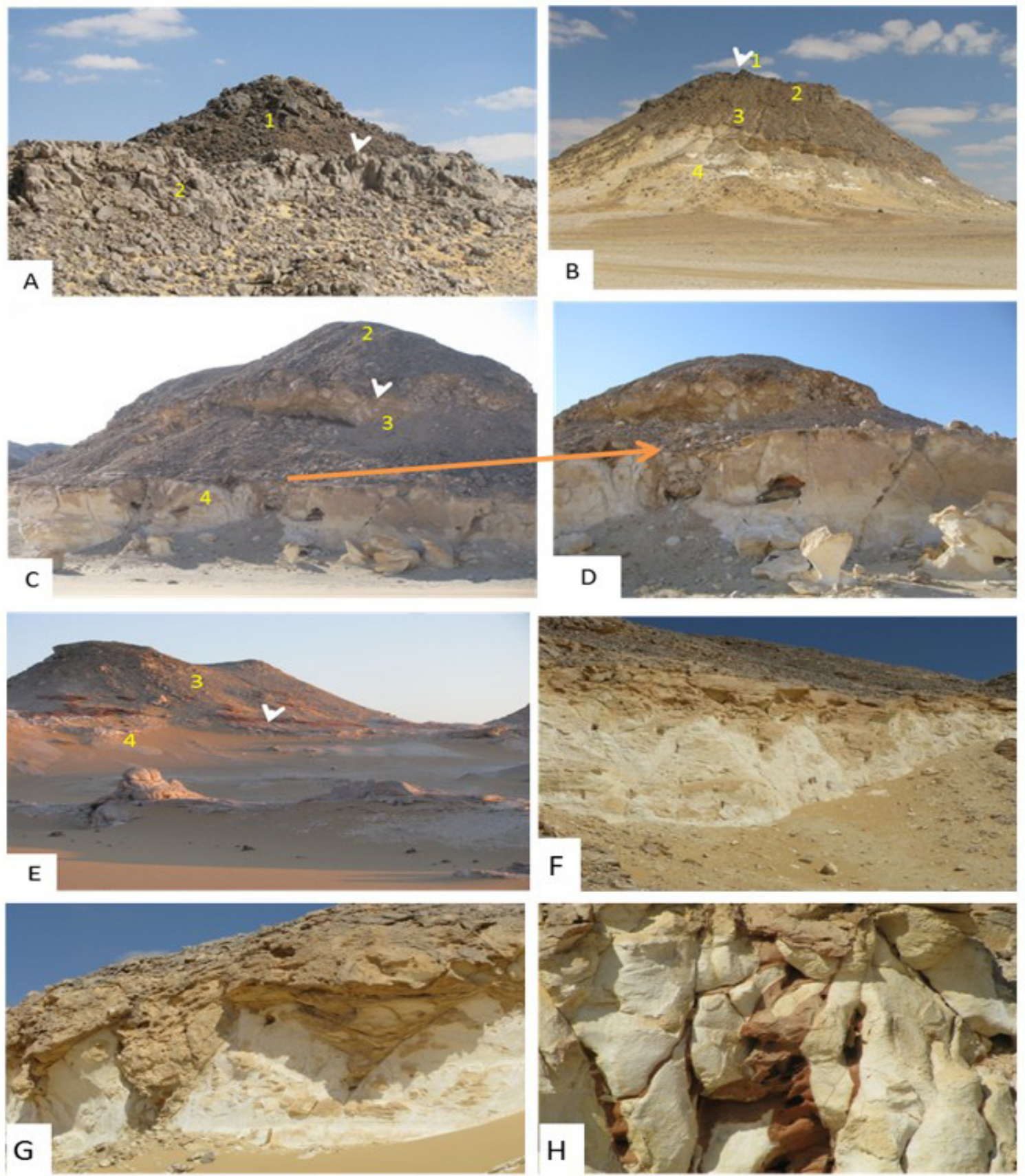

Fig. 11. A) Close-up view showing the stratigraphic break (paleokarst, MK, arrow) between the Early Eocene silicified dolostones (2) and The Miocene (Oligocene) fluvial sediments (1). B) Field photograph showing the stratigraphic sequences of the study area, from top to bottom: $1=$ relicts of the Oligocene-Miocene fluvial sediments, 2= Early Eocene karstified dolostone; 3= Paleocene chalky limestones; 4= Late Cretaceous chalky limestones. $C \&$ D) Close-up view showing the stratigraphic paleokarst boundary between the Early Eocene dolostone (1) and the Pliocene chalk (2) and between the Paleocene (3) and the underlying Late Cretaceous (4) sequences. Notice, the rubbly nature and brecciation of the Paleocene chalk (arrow), and the collapse doline developed along the Early Cretaceous -Paleocene sequence boundary. E) Red soils demarcating the boundary between the Paleocene and the Late Cretaceous sequences. F \& G) Paleokarst surface between the Maastrichtian Khoman chalk sequence and the overlying Paleocene Tarawan sequence, the surface is highly undulated and dominated by infilled V-shaped depressions and bowlshaped basins filled with chaotic clasts embedded in the RED soil matrix. H) Solution fractures (karren) filled with red soils penetrating the Late Cretaceous chalks beneath the contact with the overlying Paleocene rocks.

Egypt. J. Geo. Vol. 65 (2021) 


\section{Morphotectonic evolutionary of the exposed karst landscape}

The outcropped karstified carbonate sequences form remarkable landforms of different magnitudes and altitudes resulting from multicycles of erosion inducing karstification. The careful examination of the exposed karst landforms led to the recognition of the erosional history and denudation of the tectonically exposed carbonate sequences and the included fossilized paleokarst intervals and the sequential development of the present-day landscape (Fig. 12) and can be reviewed as follows:

The $1^{\text {st }}$ stage represents the post-Early Eocene uplifting of the highly faulted and folded Cretaceous - Early-Eocene carbonate sequences and formation of rugged mountainous relief.

The $2^{\text {nd }}$ stage displays the deposition of very hard brown fining-upward successions of conglomerates, sandstones, and siltstones of the Post-Eocene (Miocene-Oligocene !?) fluvial sequence, lapping on different stratigraphic horizons of the underlying karstified carbonate sequences. Microscopically, the conglomerates are formed of poorly sorted, subrounded to rounded quartz grains embedded in a sandy and silty ferruginous matrix. The sandstones are also of matrix-supported texture with occasional mosaic calcite cement. These fluvial sediments from distinctive high laying morphologic markers capping the summits of consumed dissected plateau and elongated hills and may denote an old paleo-erosion surface and lowering of the landscape resulted from an old erosion cycle inducing karstification and fluvial actions and plantation under vegetation cover.

The $3^{r d}$ stage illuminates the progressive destruction and denudation of the highlaying old erosion surface and related fluvial sediments during subsequent erosion cycle (post-Oligocene?), throw river incision and gradual stripping of the fluvial sediments and development of wide carbonate interfluves of different rock units with or without remnants of the fluvial sediments, and continuous incision and deepening of revers and widening of the valleys, contemporaneously with slope retreat and gradual consumption of the interfluves and formation of isolated karst ridges and cone hills (formation of fluvial karst landscape).

The $4^{\text {th }}$ stage accentuates the development of denuded karst landforms along the floor of the depressions because of progressive denudation and destruction of the carbonate residual hills and the intra-carbonate cavities, solution passages, widened fractures or karren and their internal mechanical, biogenic, and chemical precipitates.

The continues and extensive denudation of the exposed paleoerosion surfaces and related karst features and sediments led to the development of a plain of denudation marked by small-scale residual hills and remnants of the older karst features encompassing removing of the roofs of the cavities and solution passages and exposing of the cave sediments (Tables $1 \& 2$, Fig. 1319). The denuded karst features include widened joints, sinkholes, wide varieties of collapse breccias, subsurface channels, and caves. The small-scale solution features are displayed by proto-cave natural voids and fractures as well as wide varieties of crackle breccia, widened joints and fractures, small scale cavities, and openings of different shapes (e.g. cylindrical, rectangular, rounded, or irregular), ranging in diameter from few millimeters to tens of centimeters. Large scale solution openings or cavities of lenticular, wavy, or irregular shapes and up to $150 \mathrm{~cm}$ in diameter and arched upper surfaces and concave lower surfaces are often developed along bedding planes either without any obvious relation to joints or connected with vertical or inclined opened passages and solution channels. Solution channels are funnel or tabular in shape and having a gentle slope side, up to $1 \mathrm{~m}$ wide and $4 \mathrm{~m}$ deep. They appear to be developed during water infiltration into vertical joints communicating with sinking streams or lateral subsurface solution openings. These solution features are partially or completely filled by varieties of autochthonous and allochthones paleo-cave facies, briefly summarized and listed in Tables $1 \& 2$ and expressed by representative field and microscopic photographs in figures 14-20. In the final stage of denudation, the topography of the study area has been reduced until the formation of planed surface and the outcropped sequences and the enclosed karst features and sediments become completely dissected and destructed leaving behind remnants of the karst features and sediments stand out above the ground surface all over the landscape, representing a denuded karst surface. Ultimate denudation and degradation of the outcropped sequences and the included karst 
solution systems through stages 2-4 of figure 13, resulted in the development of vast planed areas along which amazing and countless residuals of the country rocks and the karst sediments dominate (Tables $1 \& 2$ and Fig. 13-19). The other important observation is the common penetrations of the exposed karst sediments by different karren forms and different generations of calcite precipitation and red soil accumulation, suggesting younger denudation by solution processes during the younger time.

\section{Stage (1): \\ Post-Early Eocene Uplifting and Development of Rugged Mountaneus Relief}

Stage (2):

Plantation and precipitations of the Miocene (Oligocene?!) Fluvial sediments above different tectonically-controlled stratigraphic levels

Stage (3):

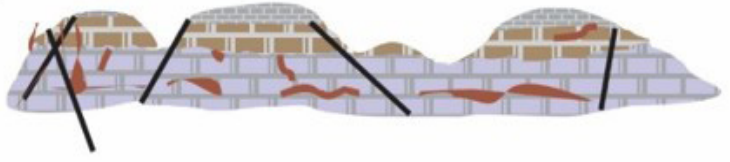

Pprogressive Denudation, Incision of rivers and stripping of the Fluvial Sediments (Post-Oligocene?), Exposing of the Fossilized Karst Features

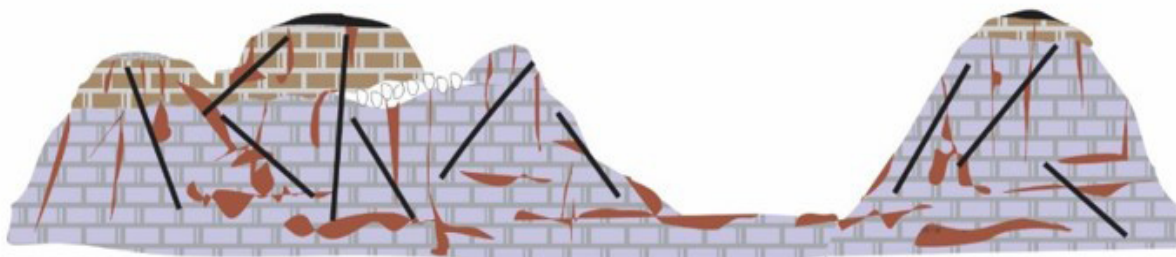

Stage (4): Development of denuded karst lanforms through continuous widening of the wadies, slope retreat and gradual consumption of of the residual karstified carbonate hills and the related intra karst features and products.

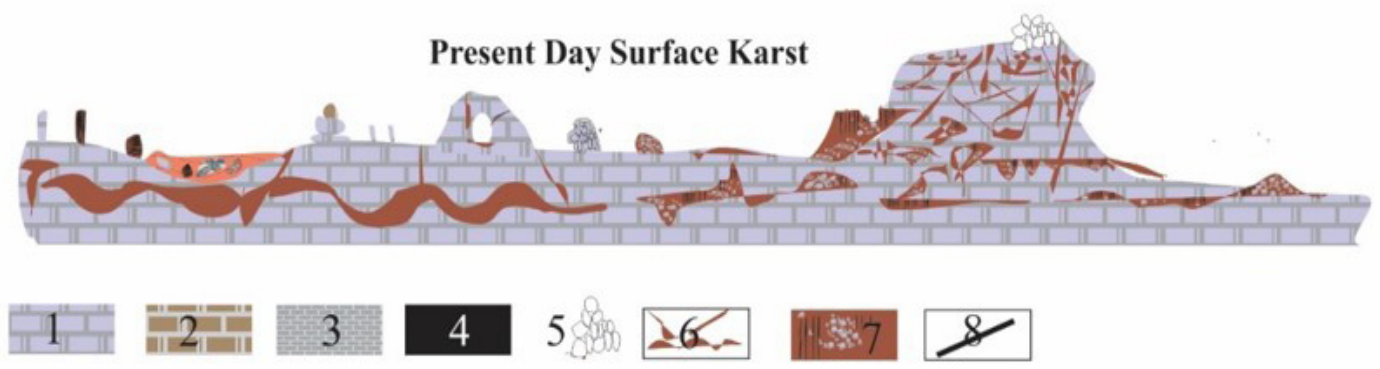

Fig. 12. Sketch drawings suggesting the geomorphotectonic evolution steps of El Sheikh Abdallah- Crystal Mountain Uvalas and development of the present-day surface karst, (not to scale), description in the text. 1= Maastractian sequence (Khoman Fm.), 2= Paleocene sequence (Tarawan Fm.), 3= Early Eocene sequence (Farafra Fm.), 4= Miocene (Oligocene?) fluvial sequence, 5= Chalk rubbles and conglomerates, $6=$ Infilled solution passages and cavities, $7=$ cave sediments (flowstones, spleothems, and red soils), $8=$ Faults and fractures.

Egypt. J. Geo. Vol. 65 (2021) 
Table 1. Summary of the recognized general paleocave facies (based on the ternary classification diagram for cavesediment fills and breccia's of Loucks (2007).

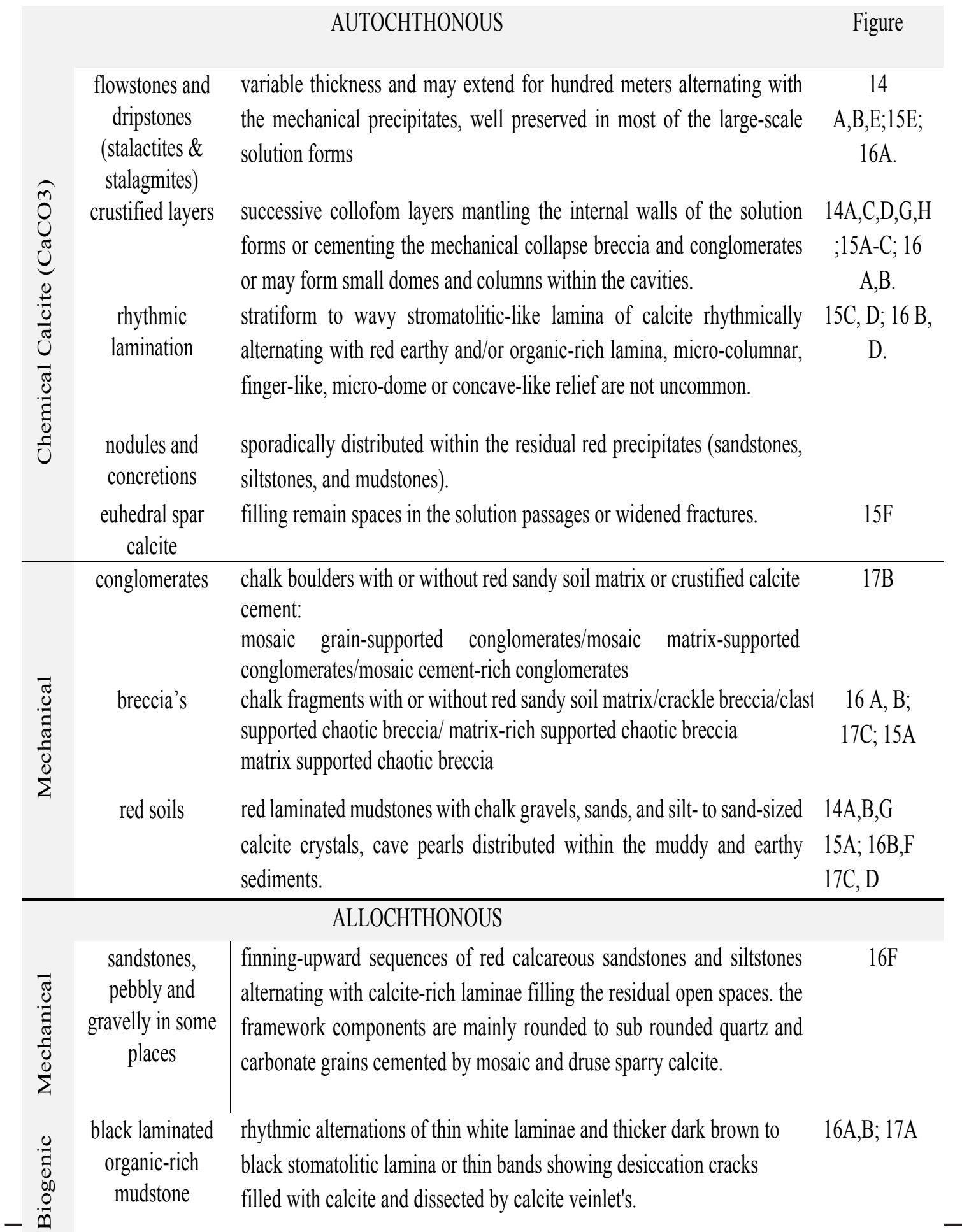


TABLE 2. The most recognizable residual features in the present-day denuded karst surface of El Sheikh Abdallah and Crystal Mountain Depressions.

\begin{tabular}{|c|c|c|c|c|c|c|}
\hline & \multirow{2}{*}{ Type/Form } & \multirow{2}{*}{$\begin{array}{l}\text { comments } \\
\text { Common }\end{array}$} & \multicolumn{3}{|c|}{ Abundance } & \multirow{2}{*}{ : } \\
\hline & & & Rare & Single & & \\
\hline \multicolumn{2}{|r|}{ Residual hills } & $\begin{array}{l}\text { mainly chalky conical hills of } \\
\text { variable diameters }\end{array}$ & $\sqrt{ }$ & & & \multirow{4}{*}{$\begin{array}{l}9 \mathrm{~A}-\mathrm{D} \\
12 \mathrm{~A}-\mathrm{F} \\
14 \mathrm{~A}-\mathrm{H} \\
15 \mathrm{~A}-\mathrm{F} \\
16 \mathrm{~A}, \mathrm{~B} 17 \mathrm{~A}, \mathrm{~F}\end{array}$} \\
\hline \multirow{9}{*}{ 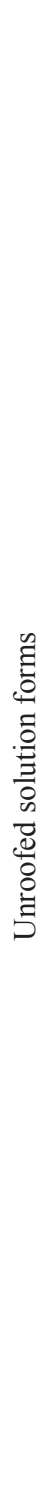 } & large \& small cavities & & & & & \\
\hline & $\begin{array}{l}\text { solution passages \& } \\
\text { channels }\end{array}$ & $\begin{array}{l}\text { representing the main property } \\
\text { of the landscape }\end{array}$ & $\sqrt{ }$ & & & \\
\hline & $\begin{array}{l}\text { highly destructed solu- } \\
\text { tion forms }\end{array}$ & $\begin{array}{l}\text { complete destruction and remo- } \\
\text { ving of cave and passage ce- } \\
\text { ilings and walls }\end{array}$ & $\sqrt{ }$ & & & \\
\hline & $\begin{array}{l}\text { layers of cave sedi- } \\
\text { ments }\end{array}$ & $\begin{array}{l}\text { widespread on the ground floor, } \\
\text { crustified calcite and/or red clas- } \\
\text { tic precipitates or thick rubbly } \\
\text { soils contain blocks of crustified } \\
\text { calcite, flowstones, dripstones, } \\
\text { and recrystallized carbonates }\end{array}$ & $\sqrt{ }$ & & & $\begin{array}{l}12 \mathrm{E} \\
14 \mathrm{E}\end{array}$ \\
\hline & $\begin{array}{l}\text { dissected shallow rid- } \\
\text { ges of sandy to grave- } \\
\text { ly red soils alternating } \\
\text { with sheeted thin flows- } \\
\text { tones }\end{array}$ & $\begin{array}{l}\text { commonly distributed within the } \\
\text { lowlands, }\end{array}$ & $\sqrt{ }$ & & & $15 \mathrm{~A}$ \\
\hline & cave remnants & forming heaps and mounds, & $\sqrt{ }$ & & & $\begin{array}{l}9 \mathrm{D} \\
18 \mathrm{~B}, \mathrm{C} \\
18 \mathrm{D}, \mathrm{A}\end{array}$ \\
\hline & bridges / arches & $\begin{array}{l}\text { formed from either the chalk } \\
\text { country rocks or crustified cave } \\
\text { breccia's }\end{array}$ & & $\sqrt{ }$ & & 18B,C \\
\hline & $\begin{array}{l}\text { subsided, dislocated, } \\
\text { and rotated blocks }\end{array}$ & $\begin{array}{l}\text { composed from all country and } \\
\text { karst components }\end{array}$ & $\sqrt{ }$ & & & $18 \mathrm{D}$ \\
\hline & $\begin{array}{l}\text { pedestal rocks /pillars/ } \\
\text { stacked rocks (statue-li- } \\
\text { ke), smooth cylindrical } \\
\text { pinnacles/pinnacle rock } \\
\text { head, isolated stone fo- } \\
\text { rest-like blocks }\end{array}$ & $\begin{array}{l}\text { consisting mainly of the country } \\
\text { rocks and/or flowstones (crusti- } \\
\text { fied calcite mixed with red soil) }\end{array}$ & $\sqrt{ }$ & & & $\begin{array}{l}18 \mathrm{E}, \mathrm{F} \\
19 \mathrm{~A}-\mathrm{F}\end{array}$ \\
\hline 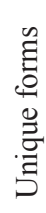 & $\begin{array}{l}\text { sphinx-like, lizard, oc- } \\
\text { topus (curtain), turtle, } \\
\text { cannon, dragon, mon- } \\
\text { key, and niche like-sha- } \\
\text { pe }\end{array}$ & $\begin{array}{l}\text { mainly formed from crustified } \\
\text { calcite layers, red soils or black } \\
\text { carboniferous mudstone and of- } \\
\text { ten penetrated by younger minor } \\
\text { karren and calcite generations }\end{array}$ & & & $\sqrt{ }$ & $20 \mathrm{~A}-\mathrm{F}$ \\
\hline
\end{tabular}

Egypt. J. Geo. Vol. 65 (2021) 

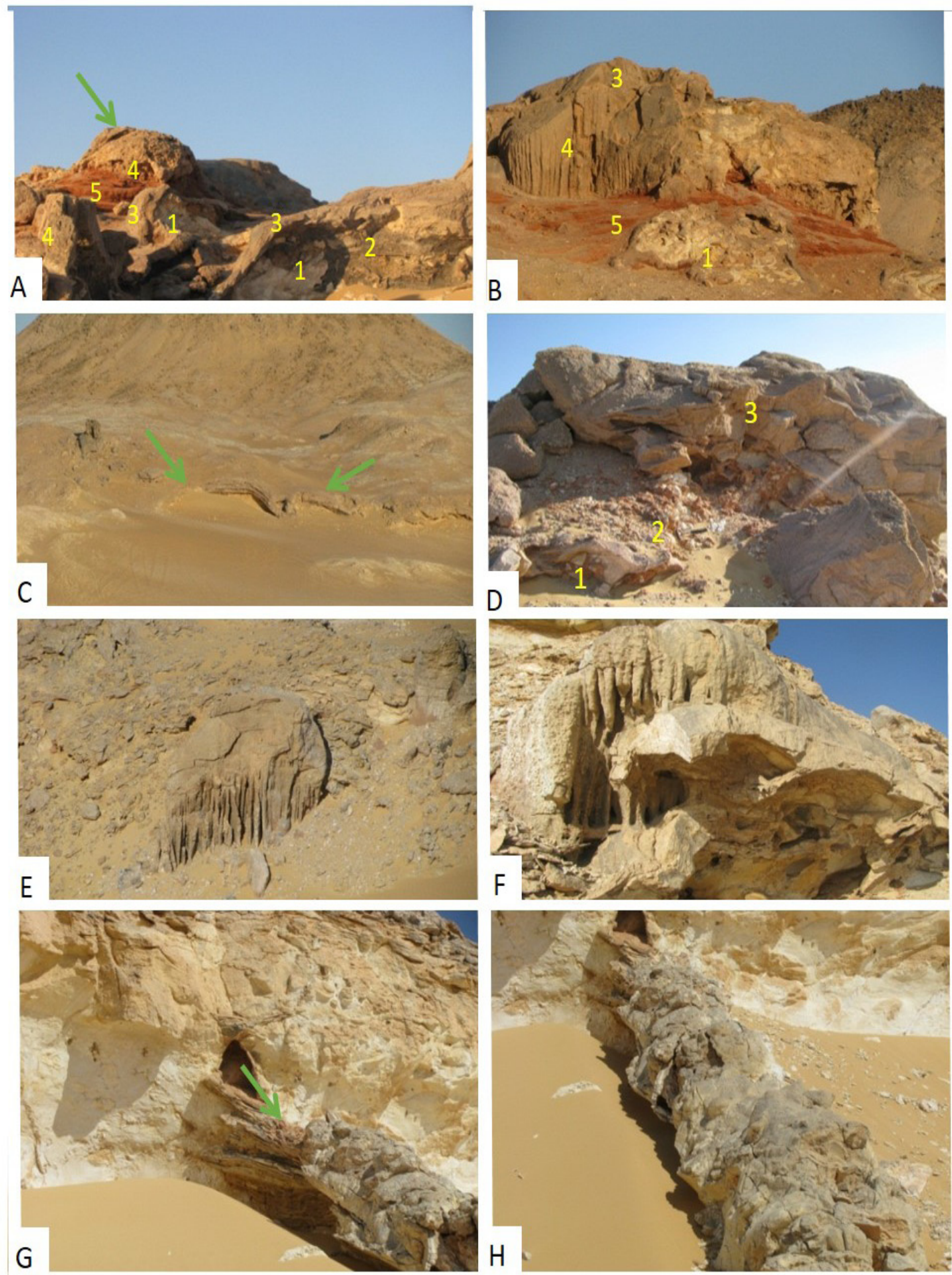

Fig. 13. (A \& B) unroofed large-scale caves showing varieties of paleo-cave facies: $1=$ collapse breccia, $2=$ laminated black carboniferous mudstone with cave pearls, $3=$ repeated layers of crucified calcite, $4=$ stalagmites and stalactites, $5=$ red soils. C) unroofed elongated cave deposits (arrows), D) close-up view of unroofed cave sediments: $1=$ collapse breccia with red soil matrix, $2=$ chalk with calcite fragments and calcite concretions embedded in the red soil matrix. $E$ \&F) close-up views of unroofed stalagmites and stalagmites (dripstone). G \& H) Uncovered inclined solution passage filled with crustified calcite mixed with red soils (arrow). 

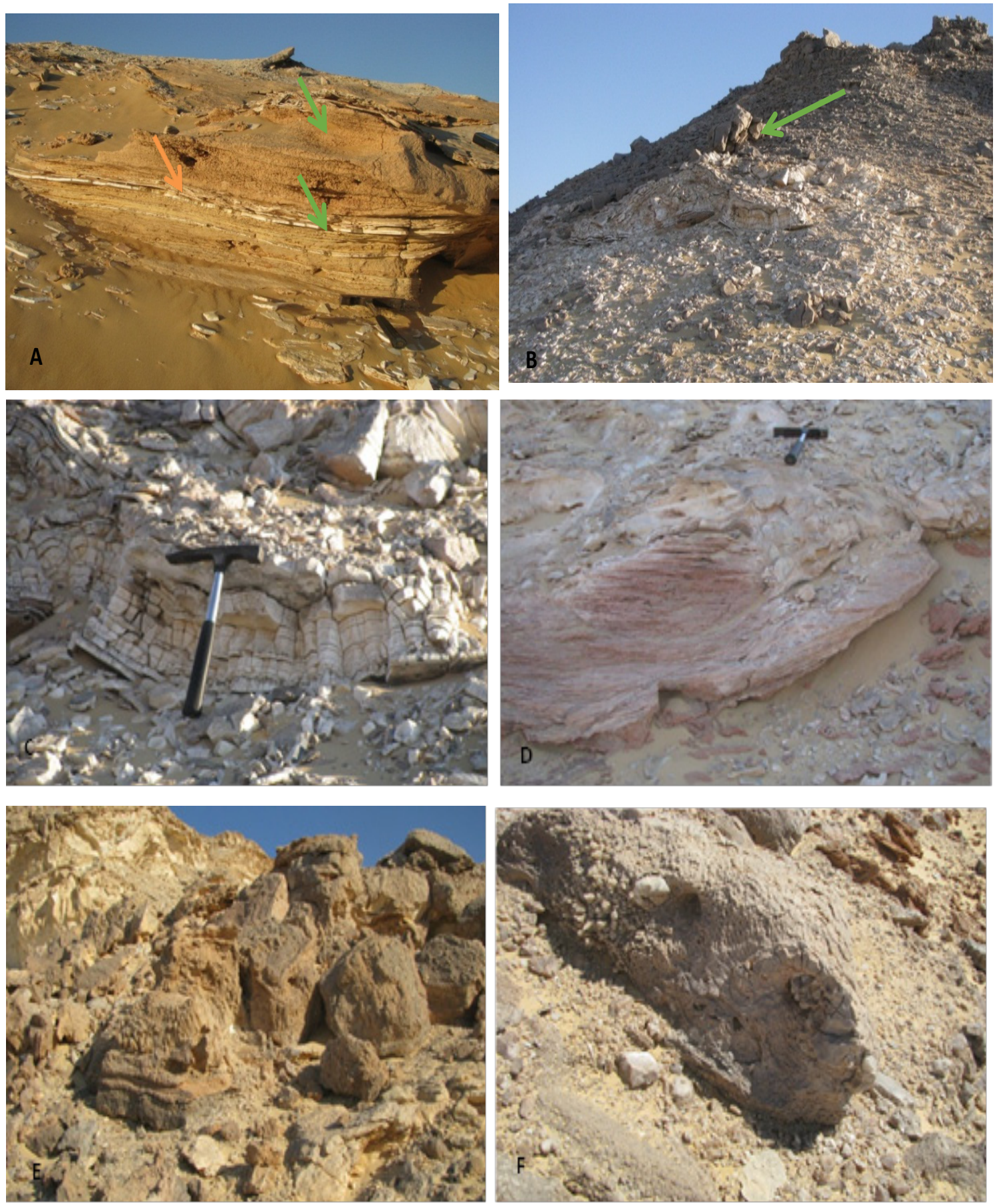

Fig. 14. A. partially to completely unroofed cave showing varieties of paleo-cave facies and cave sediments ( mainly alternation of red soils and thin sheeted flowstones). B) partially unroofed elliptical cave (arrow) filled with highly deformed cave sediments (alternation of crustified calcite and red soil layers. C) cave filling of colloform crustified calcite layers (flowstones). D) rhythmic alternations of red soils and colloform calcite, filling sediments of the unroofed smallscale cave. E) Unroofed closely spaced calcite columns, being composed of multi-generations of elongate, fibrous, and blocky calcite crystals. F) crystal aggregates of blocky and elongated calcite crystals of unroofed cave fillings, enclosed within red soils. 

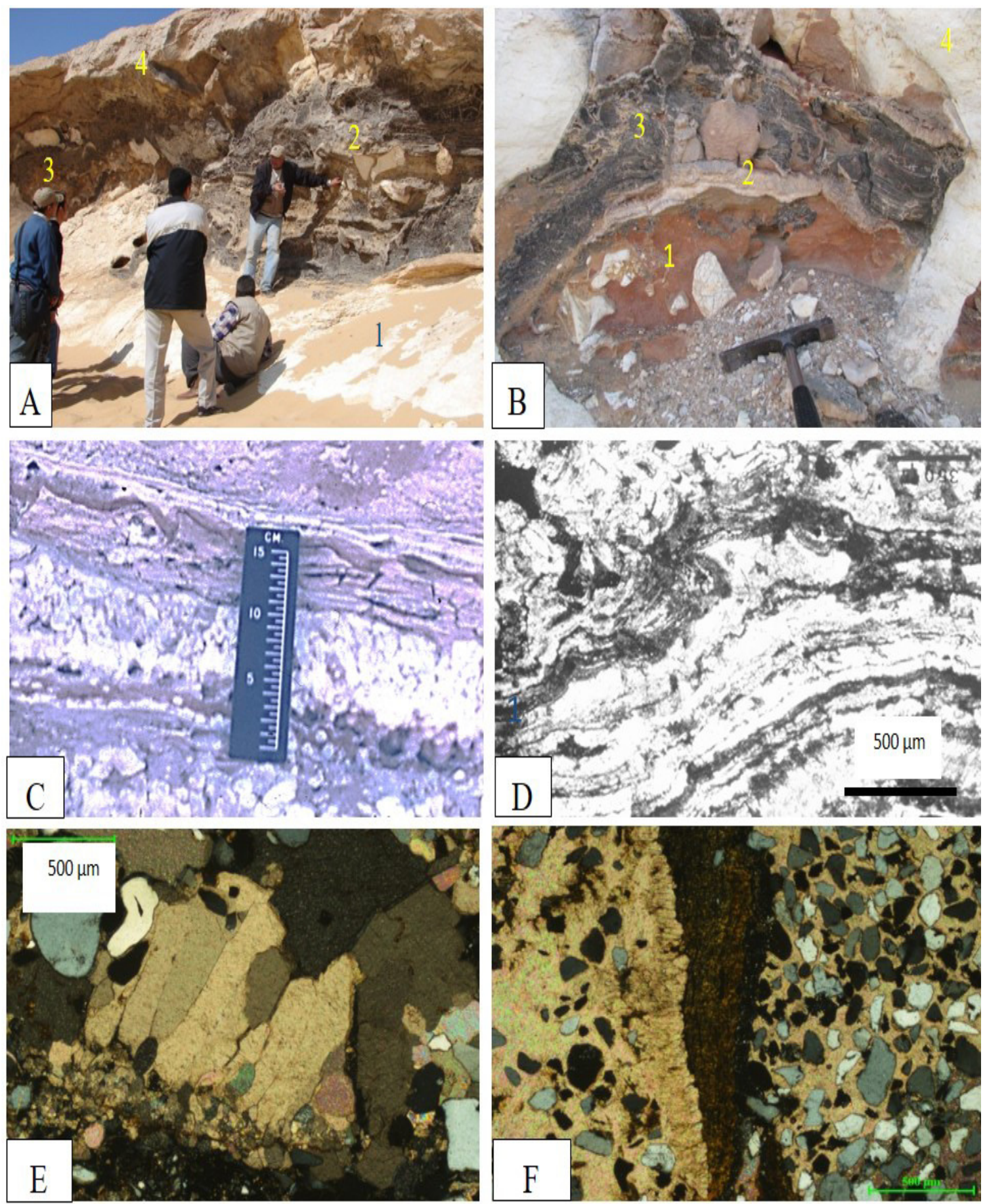

Fig. 15. A. side view of unroofed cave sediments showing: $1=$ host rock of chalky limestone representing the floor of the cave, $2=$ cave filling facies of alternating thin layers of Carbonatized mudstone and stromatolitic calcite, $3=$ collapse breccia fragments within carbonized mudstone matrix, $4=$ repeated thick layers of crustified calcite. B) close-up view of cave sediments consisting of $1=$ red soils including rock fragments of chalk and crustified calcite as well as calcite concretions, $2=$ stromatolitic calcite encrustation, $3=$ carbonatized mudstone including chaotic breccia fragments, and $4=$ younger generation of relatively thick crustified calcite layers. $C=$ close-up view of the stromatolitic calcite layers and lamina showing varieties of growth forms like concave-convex, columnar, and finger growth form. D): photomicrograph of the stromatolitic calcite layers, plane polarized $E \& F$ ) photomicrographs of the cave sediments: $E=$ druse and palisade calcite cement, $F=$ ferruginous $V$-shaped root penetrating blocky, druse and spar calcite cement of sandy red soil, Crossed polarizers. 

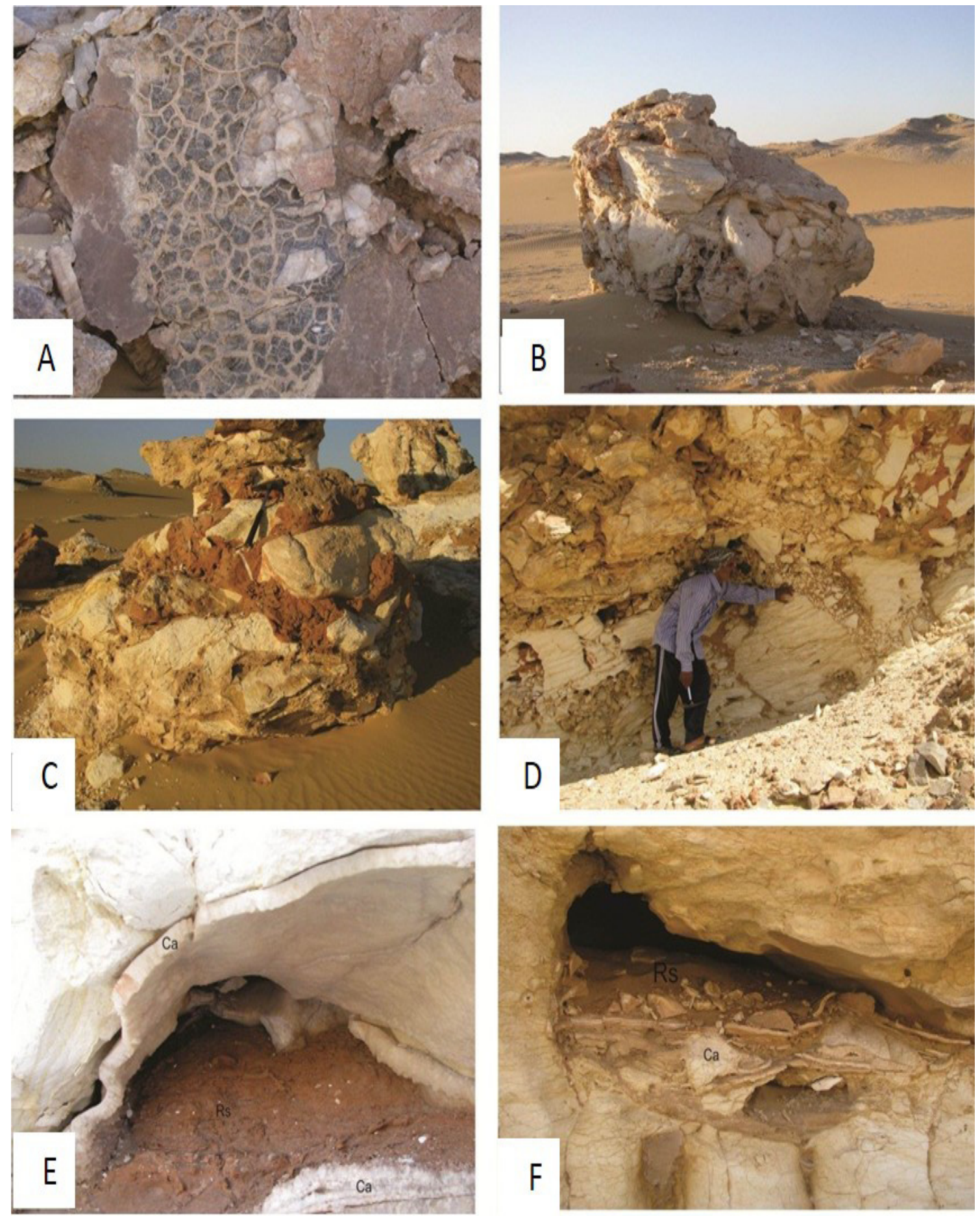

Fig. 16. A. Highly desiccated black carbonatized mudstone forming desiccation breccia cemented by multiple generations of stromatolitic crustified calcite. B) chaotic chalk conglomerate with red soil matrix and crustified calcite cement. C) Chaotic red matrix breccia. D) grain-supported in situ breccia invaded by red soils. E) small-scale solution cavity internally lined by crustified calcite (Ca) and partially filled with red soil (Rs). F) geopetal cave filling "stratigraphic up") consisting of rhythmic laminated calcite (Ca) followed by red soil (Rs). 

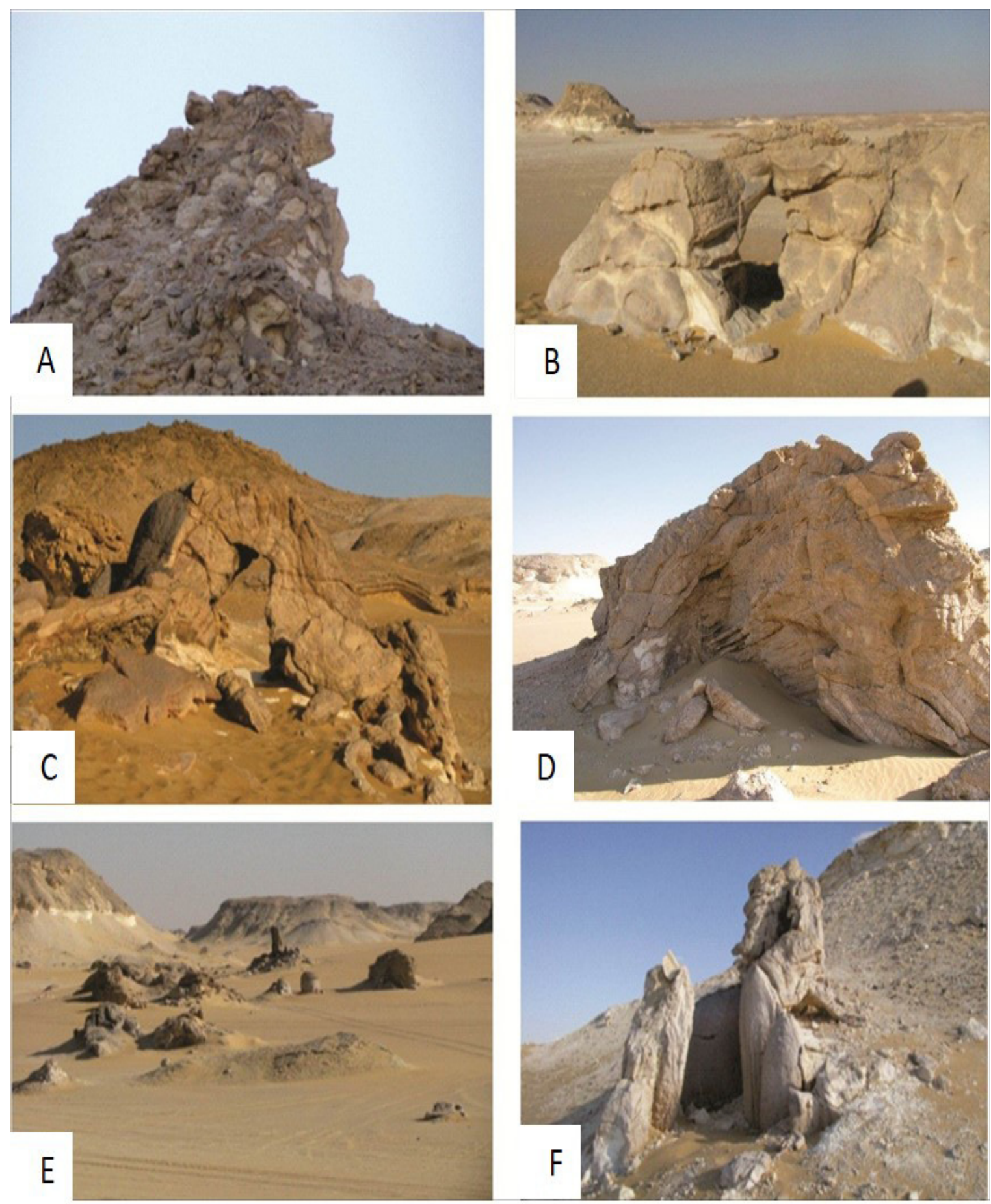

Fig. 17. A. residual mound of cave conglomerate with calcite encrustation (cockade texture). B) karst window, or small-scale solution tunnel passed through karstified chalk. C) karst window or small-scale solution tunnel passed through the remain of crustified calcite (cave carbonate sediments). D) subsided and rotated block of stalactites. E) residual pedestal rocks consisting of dense calcite stalagmites and columns. F) stacked rocks (Statue-like), entirely composed of crustified calcite and speleothems. 

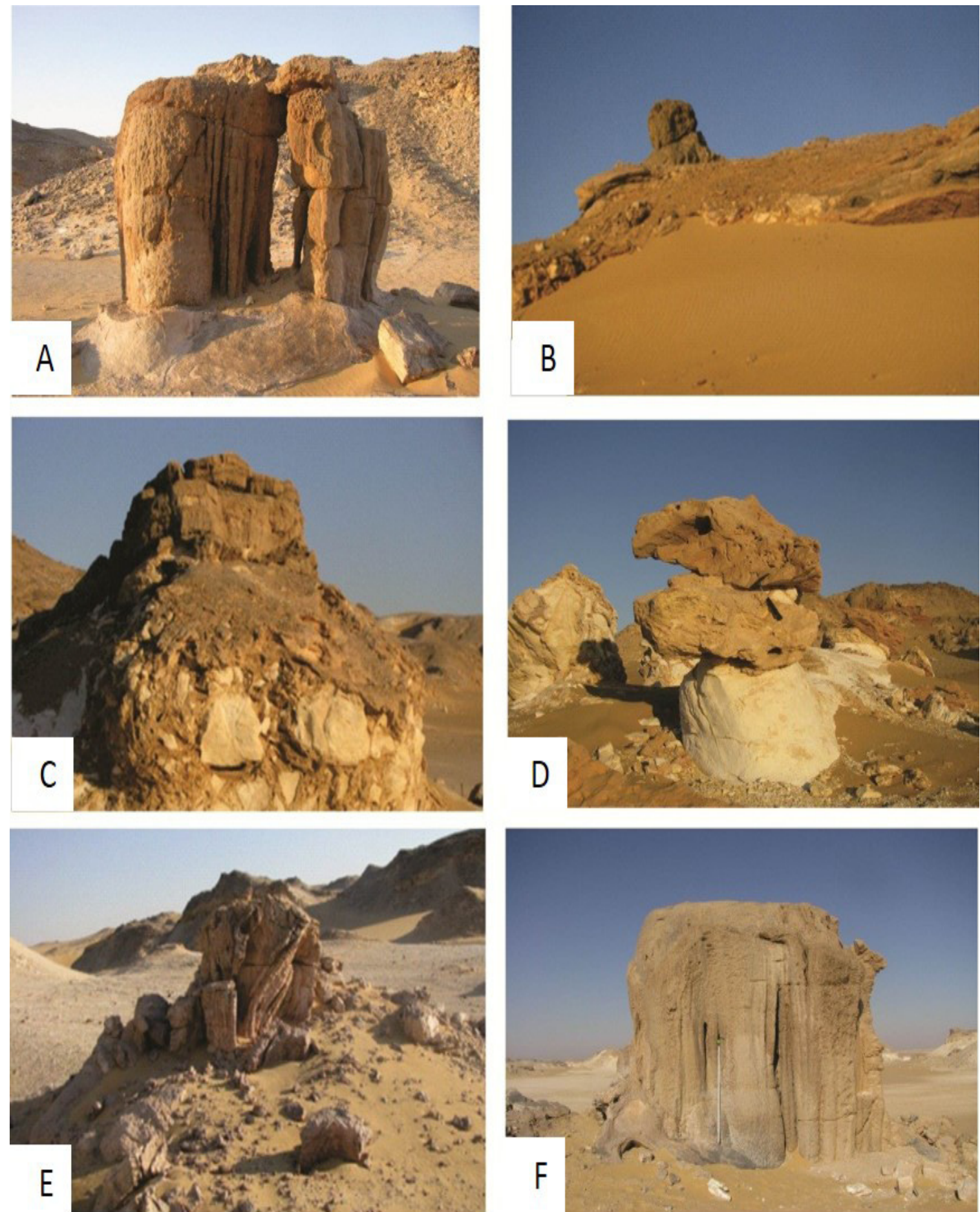

Fig. 18. A. Smooth cylindrical pinnacle and pinnacle rock head of stacked pile stalagmites. B-E) isolated stacked rocks or stone forest-like blocks, bedding plane notches "shichtflugkarren" are common. F) remains of a stone rectangular block of stacked stalagmites. 

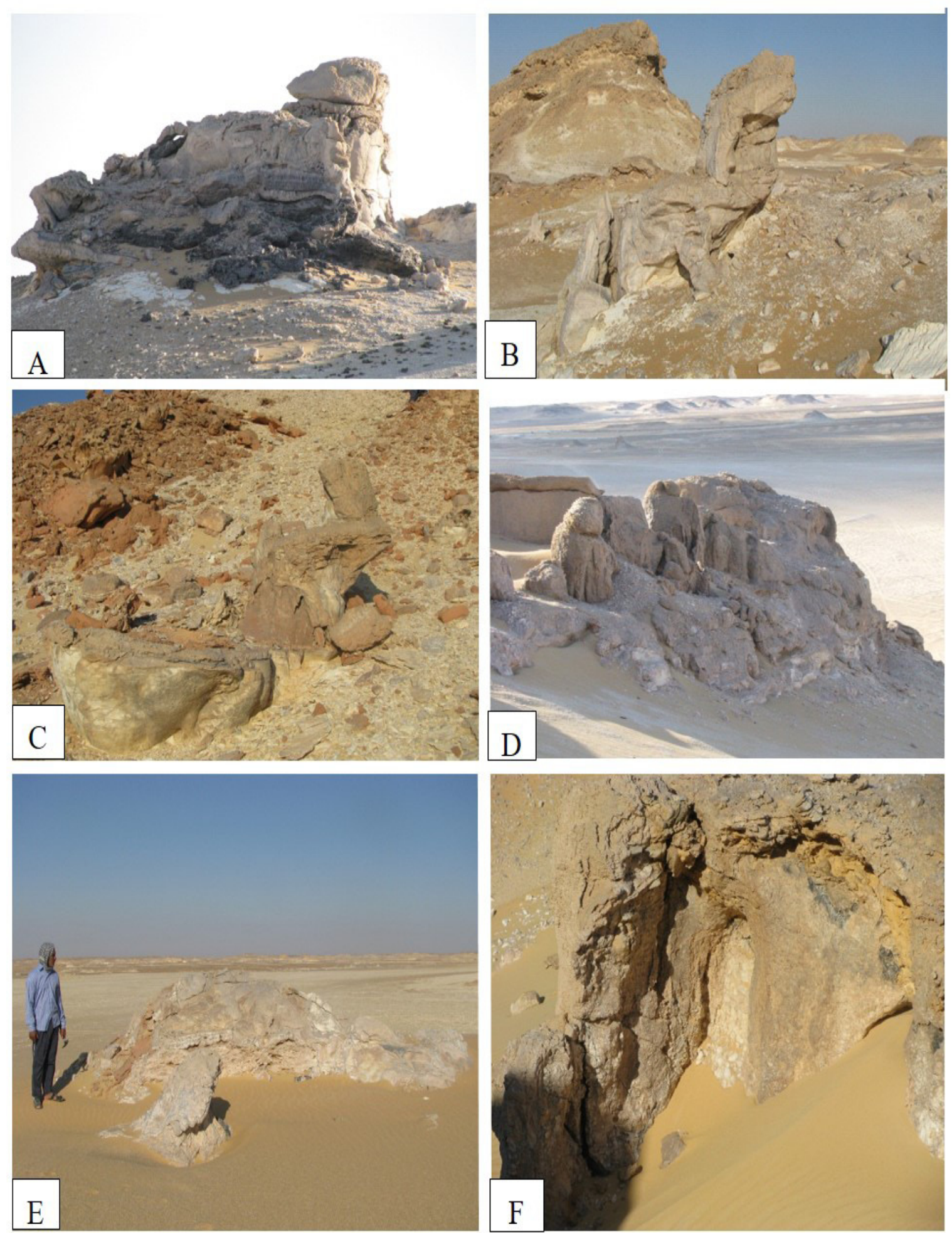

Fig. 19. Selected examples from the spectacular or eye-catching residual karst forms (built-up unroofed cave sediments) of EI Sheikh Abdallah denuded karst. A) sphinx-like form. B) lizard-like form. C) dragon-like form. D) monkey-like form. E) turtle-like form. F) niche-like form. 


\section{Conclusions}

1. El Sheikh Abdallah and Crystal Mountain Karst uvalas of Qaret El Sheihk Abdallah are a part of the White Desert National Park of El Bahariya-Farafra karst Territory, Western Desert Egypt, and represent one of the most unique karst features and attractive landscapes of the park. it comprises geomorphosites of humid paleoclimate karst carbonate features with a spectacular landscape of outstanding natural beauty that ranks and distinguishes the region as a world-famous spectacle. The White Desert National Park was established as a protectorate area in 2002 to protect these important karstic phenomena which did not occur in any other protected areas of Egypt.

2. Despite the potentials of these geomorphosites, they provide a complex geological record during the Cretaceous post-OligoceneMiocene paleo-topographic evolution and distribution of paleo-highs and paleo-lows and sea retreats, under the effect of paleokarstification cycles of humid paleoclimates. The presence of the humid karstic features and remains along with the present-day arid morphogenetic features characterizing the Western Desert maximizes their aesthetic, research, and educational values. These areas also make available sites for scientists to conduct field research and education programs in multiple fields such as geology, karstology, paleontology, paleo-hydrology, paleo-environments ...etc. Research must nevertheless be focused on the possible modifications of the karst remnants by the recent arid abrasion and sedimentation.

3. During the Cretaceous post-OligoceneMiocene time, the sea level drops and uplifting phases of the carbonate sequences of the uvalas, associated with the major transpressional inversion events of the Syrian arc (Late Cretaceous-Eocene) of the ENE- oriented Jurassic extensional fault and the successive Oligo-Miocene extensional tectonics in north Egypt caused the development of three major stratigraphic breaks (fossilized paleokarst surfaces), namely: Late CretaceousPaleocene, Paleocene-Early Eocene, and postEarly Eocene (Oligocene- Miocene).

4. Oligo-Miocene to Quaternary paleokarstification led to the sculpturing and development of the exposed karst landscape and the development of denuded unroofed spectacular karst remains along the floor of the depressions, forming a unique field of natural stone art.

5. The recognized stratigraphic breaks and their paleokarst features and the subsequent surface denudation are helped to propose a morphotectonic evolutionary model for the exposed karst landscape and the denuded karst features of El Sheikh Abdallah-Crystal Mountain uvalas.

6. The present work is based mainly on field investigations with emphasis on the relationship between the recognized rock sequences and tectonic events and with tracking the landform evolution and development of the paleo-erosion surfaces throughout the general lowering of the landscape. Also, special importance has been given to the identification and classification of the karst and cave sediments, visible on the surface. Based on that, we can conclude that the limited interpretations of the karst sediment age do not express the real chronology of the paleo-karstification phases and the related deposition-influencing processes and have still needed further detailed study such as the uranium-thorium (U-Th) dating method. The karst sediments contain autochthonous and allochthonous cave facies that represent very interesting fields for further sophisticated sedimentological, paleontological, and petrological studies, based on fine or highresolution stratigraphy of the cave sediments (even down to centimeter to millimeterscale), facies analyses, and evolution of the depositional environments, as well as determination of the sequential generations of the calcite cementation and flowstone formation. This approach enables the collection and measurement of the ages of representative cave components according to the sequence of their formation without relying on measuring the ages of the most recent components.

\section{Acknowledgment}

The authors wish to express their gratitude to the Nature Conservation Sector of the Egyptian Environmental Affairs Agency (EEAA) for support during the fieldwork. 


\section{References}

Abou Khadrah, M.A., El Aref, M.M. and Sokker, A. (1987) Karst evolution and pedological process along El Bahariya-El Farafra road, Western Desert, Egypt. 25th Annual Meeting, Geol. Soc. Egypt (abstract).

Ball, J. (1939) Contributions to the geography of Egypt: Egypt Survey and Mines Dept., Cairo, 308 p.

Bosák, P. (2008) Karst processes and time, Geologos, 14, (1): 19-36.

Brook, G., Embabi, N., Edwards, R., Cowart, J. and Dabous, A. (2002) Djara Cave in the Western Desert of Egypt: morphology and evidence of Quaternary climatic change, Cave and Karst Science, 29, (2): 57-65.

Dabous, A. and Osmond, J. (2000) U/Th isotopic study of speleothen from the Wadi Sannur Cavern, Eastern Desert of Egypt, Carbonates and Evaporites, 15 (1), 1-6.

El Akkad, S. and Issawi, B. (1963) Geology and iron ore deposits of the Bahariya Oasis. Annal. Geol. Surv., Egypt, Cairo, 18, 300 p.

El Aref, M.M. (2020) Phanerozoic stratabound/stratiform ore deposits of Egypt. In: Hamimi Z. et al. (eds.). Geology of Egypt. Chambéry: Springer International Publishing, ISBN: 978-3-030-15265-9.

El Aref, M.M (1994) Phanerozoic stratiform and stratabound deposits of Egypt, their stratigraphic, paleo-geographic, -topographic and -environmental controls. 2nd Int. Conf. Geology of the Arab World (GAW), Cairo University, 1: 97-121.

El Aref, M.M, Abu Khadra, M.A. and Lotfi, Z.H. (1987) Karst topography and karstification processes in the Eocene limestone plateau of El Bahariya Oasis, Western Desert, Egypt. Z. Geomorph., 31: 45-64.

El Aref, M.M, El Dougdoug, A. and Mesaed, A. (1991) Landform evolution and formation ferricrete duricrusts, El Heiz area, El Bahariya Depression, Western Desertm Egypt, Egypt J, Geol., 34, (1-2): 1-39.

El Aref, M.M, Hammed, M.S. and Salama, A. (2017a) Geomorphological classification and zonation of the exposed karst landforms in Bahariya- Farafra region, Western Desert Egypt, International Journal of Basic Sciences and Applied Research (IJBSAR) 6, (5): 956-965.

El Aref, M.M, Hammed, M.S and Salama, A. (2017b) Inventory and Assessment of the Geomorphosites of Bahariya -Farafra Territory, Western Desert, Egypt, International Journal of Basic Sciences and Applied Research (IJBSAR), 6, (5): 128-143.

El Emam, A., Dishopp, D. and Dunderdale, I. (1990) The structural setting of the Central Western Desert, Egypt, In: 10th Egyptian General Petroleum Corporation Seminar, 2: 30-70.

Farooqui, M., Farhoud, K.H., Mahmoud, D. and ElBarkooky, A. (2017) Petroleum potential of the interpreted Paleozoic geoseismic sequences in the South Diyur Block, Western Desert of Egypt, GeoArabia, 17, (3): 133-176.

Field, M.S. (1999) Karst Glossary. A lexicon of cave and karst terminology with special reference to environmental karst hydrology. U.S. Environmental Protection Agency, National Centre for Environmental Assessment, 201 p.

Gunnell, G.F, Winkler, A.J, Miller, E.R., Head, J.J., ElBarkooky, A.N, Abdel Gawad, M., Sanders, W.J. and Gingerich, P.D. (2016) Small vertebrates from Khasm El-Raqaba, late middle Miocene, Eastern Desert, Egypt. Historical Biology, 28 (1-2): 159-171.

Hewaidy, A.A., El-Azabi, M. H. and Farouk, Sh. (2006) Facies associations and sequence stratigraphy of the Upper Cretaceous-Lower Eocene succession in the Farafra Oasis, Western Desert, Egypt. 8th Int. Conf. Geol. Arab World (GAW 8), Cairo Univ., Egypt, II: 569-599. III, T. 4, 21-31

Klimchouk, A.B and Ford, D.C. (2000) Types of Karsts and Evolution of Hydrogeologic Settings. In: Klimchouk A. B., Ford, D. C., Palmer, A. N. \& Dreybrodt, W. (Editors). Speleogenesis; Evolution of Karst Aquifers. Huntsville, National Speleological Society of America, 45-53.

Knetsch, G. and Yallouze, M. (1955) Remarks on the Stratigraphy, Structure, and Origin of Siwa Depression, Egypt 625 origin of the Egyptian oasisdepressions, Soc. Geographie figypte Bull., 28: 21 33.

Mahsoub, M., Abul-Nasr, R., Boukhary, M., Abd El Aal, H. and Faris, M. (2012) Bio- and Sequence Stratigraphy of Upper Cretaceous - Palaeogene rocks, East Bahariya Concession, Western Desert, Egypt, Geologia Croatica, 65, (2): 109-138.

Mazzini1, A., Lupi, M., Sciarra, A., Hammed, M., Schmidt, S. and Suessenberger, A. )2019( Concentric Structures and Hydrothermal Venting in the Western Desert, Egypt. Front. Earth Sci. 7, p. 266. doi: 10.3389/ feart.2019.00266.

Egypt. J. Geo. Vol. 65 (2021) 
Mein, P. and Pickford, M. (2010) Vallesian rodents from Sheikh Abdallah, Western Desert, Egypt. Historical Biology, 22, (1-3): 224-259.

Moustafa, A.R, A. Saoudi, A. Moubasher, I.M. Ibrahim, H. Molokhia and Schwartz, B. (2003) Structural setting and tectonic evolution of the Bahariya Depression, Western Desert, Egypt, GeoArabia, 8, no. 1, p. $91-124$

Nádor, A. (1993) Paleokarsts and long-term karst evolution of the Buda Mountains, Hungary. Bulletin de la Société géographique de Liège, 29: 139-143.

NCEA,W. (2002) A Lexicon of Cave and Karst Terminology with Special Reference to Environmental Karst Hydrology. National Center for Environmental Assessment-Washington Office of Research and Development U.S. Environmental Protection Agency Washington, DC 20460 (author/ compiler- Malcolm S. Field)

Palmer, A. (1984) Geomorphic interpretation of cave features, In: La Fleur RG. (ed.), Ground water as a geomorphic agent. Allen and Unwin, Boston: 173209.

Piccini, L. (1998) Evolution of Karst caves in the Alpi Apuane (Italy): Relationship with the morphotectonic Histroy. Geogr. Fis. Dinam. Quat.

Pickford, M., Wanas, H. and Soliman, H. (2006) Indications for a humid climate in the Western Desert of Egypt, 1-10 Myr ago: evidence from Galagidae (Primates, Mammalia), Palaeoecology, 5: 935-943.

Pickford, M., Wanas, H., Pierre Mein, P., Ségalen, L. and Soliman, H. (2010) The extent of palaeokarst and fluvio-lacustrine features in the Western Desert, Egypt; Late Miocene subaerial and subterranean palaeohydrology of the Bahariya-Farafra area, Bulletin of the Tethys Geological Society, Cairo, 5: 35-42.
Said, R. (1960) New light on the origin of the Qattara Depression: Soc. Geographie figypte Bull., 33: 37 44.

Said, R. (1962) The geology of Egypt. Elsevier Sci. $1^{t d}$, Amsterdam. 337 p.

Sokker, A.M. (1991) Geomorphological, Petrological and Minerological studies on the carbonate sediments between Bahariya-Farafra,Western Desert, Egypt, Unpublished M.Sc. Thesis, Fac. Sci., Cairo Univ. 256 p.

Wanas, H., Pickford, A., Mein, P., Soliman, H. and Segalen, L. (2008) Late Miocene Karst system at Sheikh Abdalla between Bahariya and Farafra, Western Desert, Egypt: Implication for paleclimate and geomorphology, Acta Geolgica, 7: 475-487.

Xu, X., Chen, Q., Chu, C., Li,G., Liu, C. and Shi, Z. (2017) Tectonic evolution and paleokarstification of carbonate rocks in the Paleozoic Tarim Basin, Carbonates $\quad$ Evaporites, 32: 487-496. https://doi.org/10.1007/s13146-016-0307-4

Zhang, M.L., Liu, G.Y. and Deng, Z.Q. (2010) Paleokarstification and Mineralization of Late Cretaceous in Guangxi Province, Geological Publishing House, Beijing (in Chinese). 


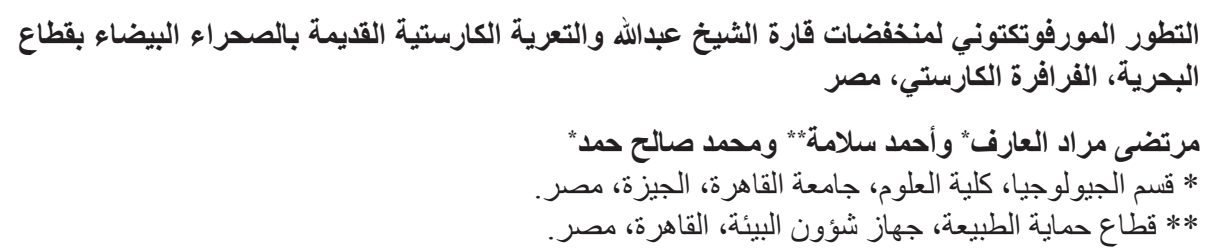

تَعرض تتابعات الصخور الجيرية لعصري الطباثبيري والإيوسين المبكربمنطقة الصحراء البيضاء وسط الصحراء

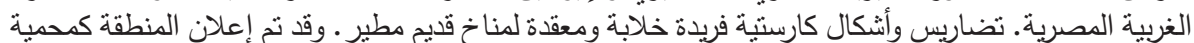

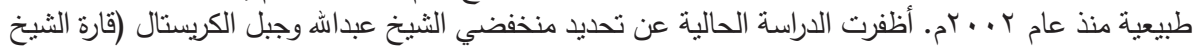

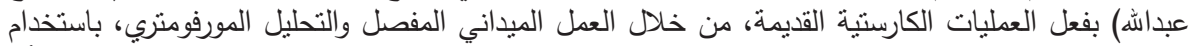

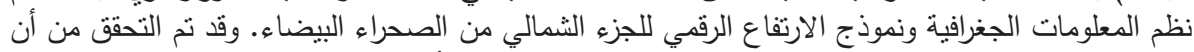

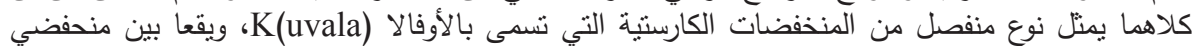

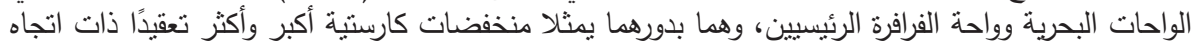

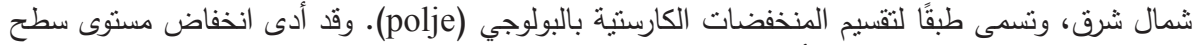

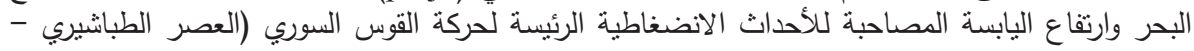

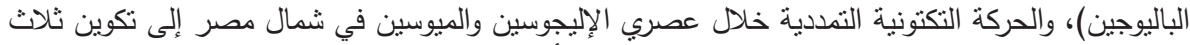

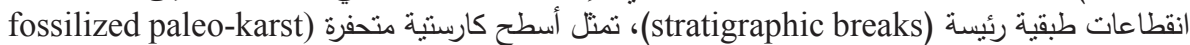

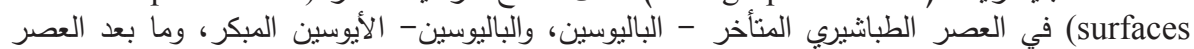
الأيوسيني المبكر (أوليجوسين - ميوسين).

وقد تم التعرف على سمات ورواسب الكارست القديم ووصفها على طول هذه الأسطح المتحفرة. وقد

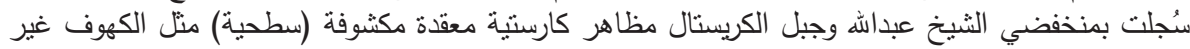

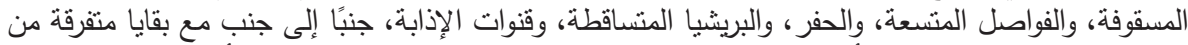

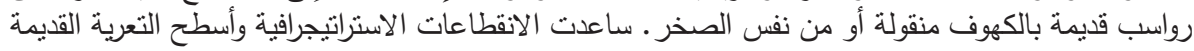

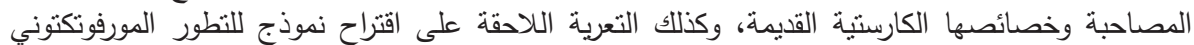
للأشكال الطبيعية ومظاهر التعرية الكارستية بمنخفضي وكية الثيخ عبدالهه وجبل الكربستال. 